University of Nebraska - Lincoln

DigitalCommons@University of Nebraska - Lincoln

4-19-2008

\title{
Occurrence and Fate of Pesticides in Four Contrasting Agricultural Settings in the United States
}

\author{
Gregory V. Steele \\ U.S. Geological Survey \\ Henry M. Johnson \\ U.S. Geological Survey, hjohnson@usgs.gov \\ Mark W. Sandstrom \\ U.S. Geological Survey \\ Paul D. Capel \\ U.S. Geological Survey \\ Jack E. Barbash \\ U.S. Geological Survey
}

Follow this and additional works at: https://digitalcommons.unl.edu/usgsstaffpub

Part of the Earth Sciences Commons

Steele, Gregory V.; Johnson, Henry M.; Sandstrom, Mark W.; Capel, Paul D.; and Barbash, Jack E., "Occurrence and Fate of Pesticides in Four Contrasting Agricultural Settings in the United States" (2008). USGS Staff -- Published Research. 2.

https://digitalcommons.unl.edu/usgsstaffpub/2

This Article is brought to you for free and open access by the US Geological Survey at DigitalCommons@University of Nebraska - Lincoln. It has been accepted for inclusion in USGS Staff -- Published Research by an authorized administrator of DigitalCommons@University of Nebraska - Lincoln. 


\title{
Occurrence and Fate of Pesticides in Four Contrasting Agricultural Settings in the United States
}

\author{
Gregory V. Steele, ${ }^{*}$ Henry M. Johnson, Mark W. Sandstrom, Paul D. Capel, and Jack E. Barbash USGS
}

Occurrence and fate of 45 pesticides and 40 pesticide degradates were investigated in four contrasting agricultural settings - in Maryland, Nebraska, California, and Washington. Primary crops included corn at all sites, soybeans in Maryland, orchards in California and Washington, and vineyards in Washington. Pesticides and pesticide degradates detected in water samples from all four areas were predominantly from two classes of herbicides-triazines and chloroacetanilides; insecticides and fungicides were not present in the shallow ground water. In most samples, pesticide degradates greatly exceeded the concentrations of parent pesticide. In samples from Nebraska, the parent pesticide atrazine [6-chloro- $N$-ethyl- $N^{\prime}$-(1-methylethyl)-1,3,5-triazine-2,4diamine] was about the same concentration as the degradate, but in samples from Maryland and California atrazine concentrations were substantially smaller than its degradate. Simazine [6-chloro$N, N^{\prime}$-diethyl-1,3,5-triazine-2,4-diamine], the second most detected triazine, was detected in ground water from Maryland, California, and Washington. Metolachlor [2-chloro- $N$-(2-ethyl6-methylphenyl)- $N$-(2-methoxy-1-methylethyl)acetamide] rarely was detected without its degradates, and when they were detected in the same sample metolachlor always had smaller concentrations. The Root-Zone Water-Quality Model was used to examine the occurrence and fate of metolachlor at the Maryland site. Simulations accurately predicted which metolachlor degradate would be predominant in the unsaturated zone. In analyses of relations among redox indicators and pesticide variance, apparent age, concentrations of dissolved oxygen, and excess nitrogen gas (from denitrification) were important indicators of the presence and concentration of pesticides in these ground water systems.

Copyright $\odot 2008$ by the American Society of Agronomy, Crop Science Society of America, and Soil Science Society of America. All rights reserved. No part of this periodical may be reproduced or transmitted in any form or by any means, electronic or mechanical, including photocopying, recording, or any information storage and retrieval system, without permission in writing from the publisher.

Published in J. Environ. Qual. 37:1116-1132 (2008). doi:10.2134/jeq2007.0166

Received 3 Apr. 2007.

*Corresponding author (gvsteele@usgs.gov).

(c) ASA, CSSA, SSSA

677 S. Segoe Rd., Madison, WI 53711 USA
Tumerous studies over the past four decades have indicated that 1 the downward and subsequent subsurface transport of pesticides applied at the land surface in agricultural areas can contribute to contamination of ground water by these compounds and their degradates (Barbash and Resek, 1996; Kalkhoff et al., 1998; Bosch and Truman, 2002; Delin and Landon, 2002; Panno and Kelly, 2004; Postle et al., 2004; Gilliom et al., 2006; McMahon et al., 2006). The likelihood of detecting pesticides in ground water is controlled by myriad factors, including the intensity of pesticide application, the timing of applications relative to major recharge events, the amount and frequency of precipitation or irrigation, the depth to the water table, soil properties (e.g., permeability, available water capacity, organic carbon content), and land management practices such as the use of subsurface drains, irrigation, or conservation tillage (Barbash and Resek, 1996; Kolpin, 1997; Barbash et al., 1999; Kolpin et al., 2002; Gilliom et al., 2006; Hancock et al., 2008). For pesticides that undergo transformation that is relatively rapid in comparison with the time scale of transport in the subsurface (i.e., above or below the water table), degradates — rather than the parent compound - may be the predominant form that reaches ground water in detectable concentrations (Kolpin et al., 1996, 1997; Kalkhoff et al., 1998; Groschen et al., 2004; Scribner et al., 2005).

The rates of many pesticide transformations in the subsurface have been found to be largest within the root zone and diminish with depth. For photochemical reactions, the products of these transformations have been found to be more prevalent at the land surface than within the soil (Crespín et al., 2001). Similarly, the rates of biotransformation reactions generally are highest within surficial soils and decrease with increasing depth. Reductions in the rates of biotransformation reactions with depth are likely to be the result of depth-related decreases in microbial populations and the organic matter on which they feed (Ou et al., 1986; Veeh et al., 1996; Larsen et al., 2000; Accinelli et al., 2001; Vinther et al., 2001).

The relative rates at which pesticides, their degradates, and other solutes migrate through the subsurface are inversely related to their respective tendencies to sorb to soil and other geologic materials (Freeze and Cherry, 1979). For soils and sediments with

G.V. Steele, U.S. Geological Survey, 5231 South 19th St., Lincoln, NE 68512. H.M Johnson, U.S. Geological Survey, 2130 SW 5th Ave., Portland, OR 97201. M.W. Sandstrom, U.S. Geological Survey, Box 25046 Denver Federal Center, Lakewood, CO 80225. P.D. Capel, U.S. Geological Survey, 122 Civil Engineering Building, 500 Pillsbury Drive, SE, Minneapolis, MN 55455. J.E. Barbash, U.S. Geological Survey, 934 Broadway, Suite 300, Tacoma, WA 98402.

Abbreviations: $E S A$, ethanesulfonic acid; $f_{{ }_{o c}^{\prime}}$ mass fraction of organic carbon in soil (dimensionless); $\mathrm{K}_{\mathrm{oc}}$, soil organic carbon-water partition coefficient; OXA, oxanilic acid; RZWQM, root-zone water-quality model; $S A A$, sufinylacetic acid; $t_{1 / 2, \text { soil’ }}$ soil dissipation half-life; UZ, unsaturated zone. 
moderate to high levels of organic carbon-i.e., roughly $0.1 \%$ or more by weight (mass fraction of organic carbon in soil [ $\left.\mathrm{f}_{\mathrm{oc}}\right]$; $f_{o c} \geq 0.001$ - - the relative tendencies of dissolved non-ionic solutes to sorb to earth materials seem to be directly related to the affinities of the compounds for soil organic matter (McCarty et al., 1981) and thus to their soil organic-matter-water partition coefficient $\left(\mathrm{K}_{\mathrm{oc}}\right)$. For organic solutes that may be present in ionic form within the range of environmentally relevant $\mathrm{pH}$ (such as the ethanesulfonic acid [ESA] and oxanilic acid [OXA] degradates examined for this study), sorption is governed by a balance among the relative tendencies of the ion to engage in hydrophobic, electrostatic, and specific chemical interactions with the solid phase and by solution factors (e.g., $\mathrm{pH}$, ionic strength, and temperature) that may control the relative proportion of the ionized form that is present (Schwarzenbach et al., 1993).

This paper focuses primarily on the chloroacetanilide and triazine herbicides, pesticides that are among those used most extensively in agriculture in the USA (Kiely et al., 2004). The chloroacetanilide herbicides of principal interest include acetochlor [2-chloro- $N$-(ethoxymethyl)- $N$-(2-ethyl6-methylphenyl)acetamide], alachlor [2-chloro-N-(2,6-diethylphenyl)-N-(methoxymethyl)acetamide], and metolachlor, which undergo transformation relatively rapidly in aerobic soil but much more slowly in water alone (Gilliom et al., 2006). Research has shown that these compounds may be transformed by a relatively large number of pathways in the hydrologic system (many of them requiring microbial assistance), resulting in the production of at least 12 degradates for acetochlor, 22 for alachlor, and 21 for metolachlor (Stamper and Tuovinen, 1998; Lee and Strahan, 2003; Hladik et al., 2005).

The degradates that have been examined most extensively for acetochlor, alachlor, and metolachlor have been their ESA and OXA metabolites (see transformation pathway diagrams for the chloroacetanilides in Capel et al., 2008). Despite the relatively high frequency with which ESA and OXA have been detected in surface and ground water (e.g., Kalkhoff et al., 1998; Phillips et al., 1999; Groschen et al., 2004; Mills et al., 2005) and the extensive use of their parent compounds, few published data seem to be available with regard to the partitioning properties or persistence of these degradates. Consequently, several of the $\mathrm{K}_{\mathrm{oc}}$ values for these and other chloroacetanilide degradates were estimated on the basis of their chemical structures using quantitative structure-property relations (Capel et al., 2008). Although the absolute magnitudes of these estimated values are more uncertain than would have been the case for measured values, their relative magnitudes derived from quantitative structure-property relations indicate that these degradates are less strongly sorbed to soil, and therefore more mobile in the subsurface, than their parent compounds. Although little information seems to be available in the published literature on the reactivity of chloroacetanilide degradates, the high frequencies with which the ESA and OXA degradates have been detected in the hydrologic system indicate that these compounds are substantially more persistent at or below the land surface than are their parent compounds.

Among the triazine herbicides, atrazine and simazine are the main focus of this paper, and deethylatrazine [2-amino-4-chloro- 6-(isopropylamino)-s-triazine] was the only triazine degradate analyzed in the study described herein. Although atrazine has been used and studied much more extensively than simazine, transformations of both compounds in the environment may occur through abiotic or microbial mechanisms (see transformation pathway diagrams for triazines in Capel et al., 2008). One group of triazine transformation reactions that seems to require microbial assistance involves the nonphotochemical oxidation of one or both of the alkyl side chains to form deethylatrazine and other products that are generally less hydrophobic than their parent compounds (Barbash and Resek, 1996; Bayless, 2001). Frequencies of detection of deethylatrazine in ground water are usually comparable to those of atrazine itself (Barbash and Resek, 1996; Kolpin et al., 2000). This observation is consistent with previous work (e.g., Winkelmann and Klaine, 1991; Kruger et al., 1993), demonstrating that microorganisms oxidize the ethyl group of atrazine (to form deethylatrazine) much more rapidly than the isopropyl group (to form deisopropylatrazine [2-amino-4-chloro6-(ethylamino)-s-triazine]).

Although numerous studies over the past four decades have examined the occurrence of pesticides and their degradates in ground water, only a relatively small number of investigations have considered the transport and fate of these compounds within ground water flow systems (e.g., Agertved et al., 1992; Barbash and Resek, 1996 and references therein; Fenelon and Moore, 1998; Burow et al., 1999; Tesoriero et al., 2000, 2001, 2007; Puckett and Hughes, 2005). The purpose of the study described herein was to assess the occurrence and fate of pesticides - particularly triazine and chloroacetanilide herbicides and their degradates - in ground water flow systems within four contrasting agricultural settings in Maryland (MD), Nebraska (NE), California (CA), and Washington (WA). The patterns of detection of these compounds in ground water and their fate are discussed in relation to (i) the physicochemical properties of the compounds that control their transport in the subsurface; (ii) aquifer properties, including redox conditions; (iii) the residence time (or age) of the ground water; and (iv) the concentrations of pesticides in the deepest parts of the unsaturated zone (UZ).

\section{Methods}

At each study site, wells were installed in transects along a conceptualized flow system starting in a recharge area in the agricultural uplands and ending in a discharge area adjacent to a stream (Fig. 1). These transects of wells, or flow-system wells, ranged in length from $450 \mathrm{~m}$ (MD) to $4200 \mathrm{~m}$ (WA). In addition, at each site, lysimeters were installed at shallow depths above some of the flow-system wells to enable collection and analysis of samples to characterize the quality of water recharging the shallow aquifers, and one to five additional areal wells were installed or located afield of the flow system to enable collection and analysis of samples to characterize regional variations in water level and chemistry. At all sites, wells were installed using hollow-stem auger or mud-rotary drilling techniques and were completed in the surficial aquifer within $50 \mathrm{~m}$ of land surface. All wells were constructed of $5.08-\mathrm{cm}$ inner diameter PVC cas- 
(A) Maryland Study Site

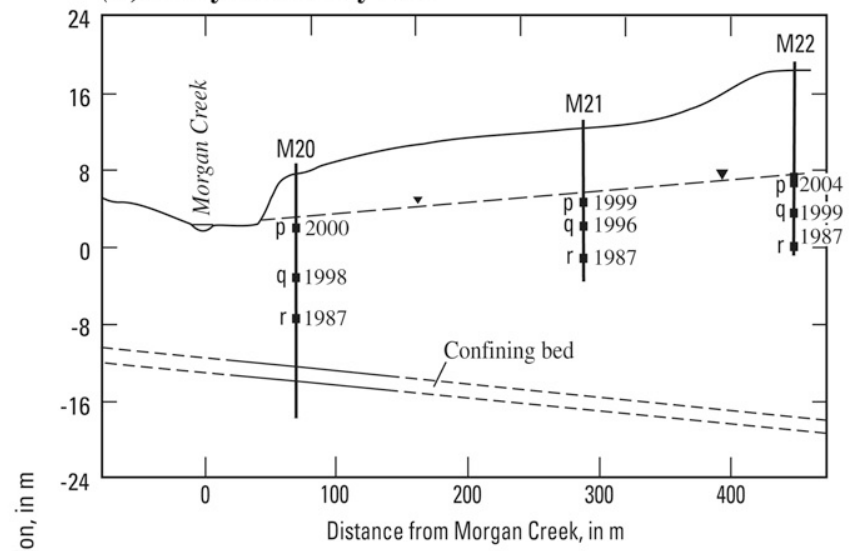

(C) California Study Site

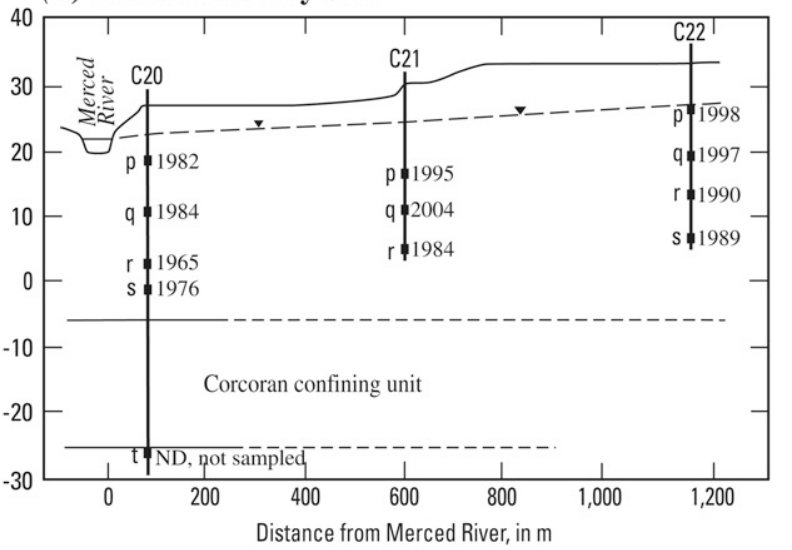

(B) Nebraska Study Site

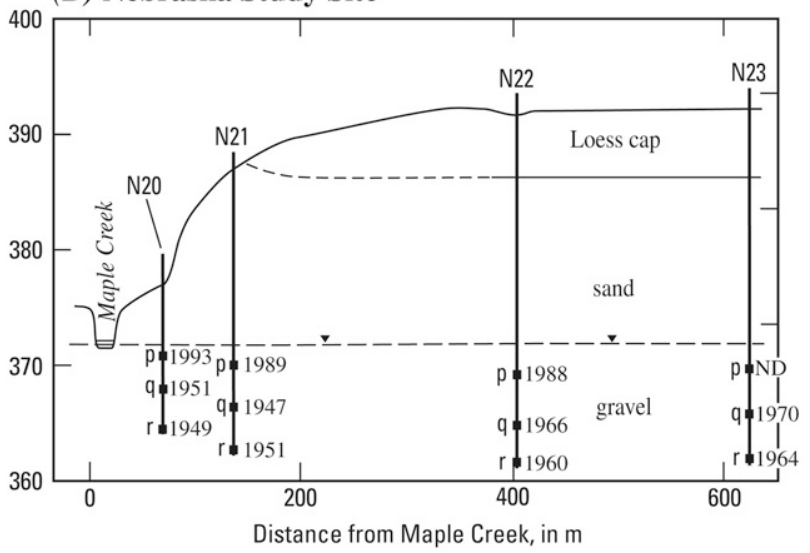

(D) Washington Study Site

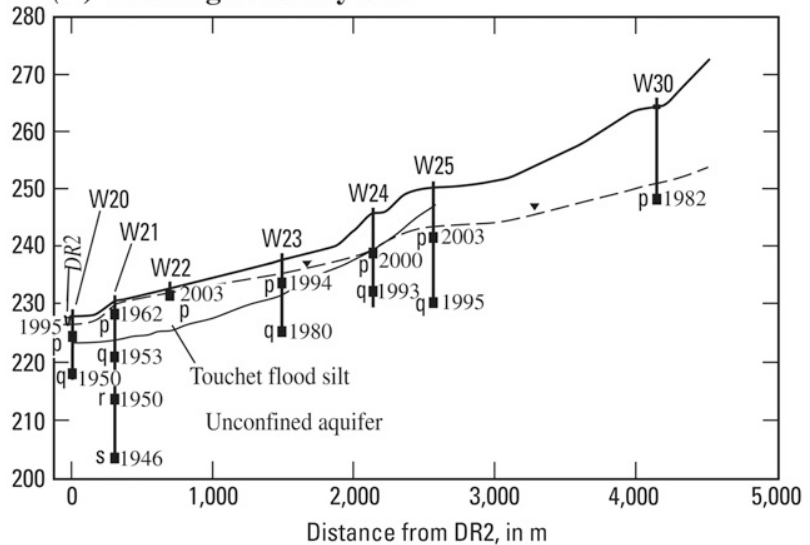

EXPLANATION

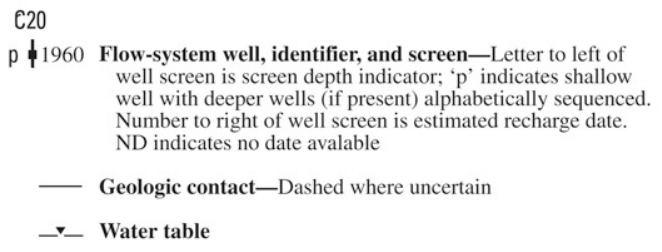

Fig. 1. Cross-section views of flow systems showing well-nest locations at the study sites in (A) Maryland, (B) Nebraska, (C) California, and (D) Washington.

ing and slotted screen $(0.0254-\mathrm{cm}$ slot in lengths of $0.61,1.52$, or $3.05 \mathrm{~m}$ ). Length of well screens ranged from 0.6 to $1.3 \mathrm{~m}$ in flow-system wells and from 0.9 to $3 \mathrm{~m}$ in areally distributed wells. Typically, wells were installed in clusters of two to three, but the number of wells in each "cluster" ranged from one to eight. The total network consisted of 59 wells among four sites. More details about individual wells and the well numbering system (Fig. 1) can be found in Capel et al. (2008).

During installation of flow-system wells, samples of aquifer material were collected from the screened interval. Samples from MD, CA, and WA were collected with a split-spoon sampler. Samples from NE were collected using the hydraulic push method. Samples of sediment from selected depth intervals were analyzed for particle size, bulk density, iron minerals, reduced sulfur (pyritic sulfur and acid volatile sulfide), organic carbon, and pesticides. Samples of aquifer material collected at the screened interval during well installation were analyzed for pesticides at 29 wells (MD, 11 wells; NE, 1 well; CA, 9 wells; WA, 8 wells).
Analysis was done on 67 pesticides or pesticide degradates in these samples and in the aqueous phase; however, analysis was not done on 18 compounds including the degradates of the chloroacetanilide herbicides in the solid phase (Capel et al., 2008).

Seventy-nine ground water samples, of which 20 were quality assurance samples (replicates, blanks, or spikes), were collected during 2004. The 59 environmental samples were analyzed for 45 parent pesticides and 40 degradates, along with nutrients, common ions, and selected trace elements. Quality assurance samples were analyzed for a subset of the environmental samples constituents (e.g., a single replicate was analyzed for a single constituent such as pesticides, nutrients, common ions, or trace elements). Physical properties of the water, including specific conductance, $\mathrm{pH}$, temperature, and dissolved oxygen, were measured at the time of sample collection. Samples collected from the flow-system wells were analyzed for dissolved gases and for chlorofluorocarbon, tritium $\left({ }^{3} \mathrm{H}\right)$, and/or sulfur hexafluoride to determine apparent recharge dates. Estimates of apparent age were 
Table 1. Characteristics of study sites in Maryland, Nebraska, California, and Washington.

\begin{tabular}{|c|c|c|c|c|}
\hline Site & Morgan Creek, Maryland & Maple Creek, Nebraska & Lower Merced River, California & Granger Drain, Washington \\
\hline Environmental setting & $\begin{array}{l}\text { representative of corn and } \\
\text { soybean row cropping in } \\
\text { the Atlantic Coastal Plain }\end{array}$ & $\begin{array}{l}\text { representative of } \\
\text { corn and soybean } \\
\text { row cropping in the } \\
\text { northern Great Plains } \\
\text { and western Corn Belt }\end{array}$ & $\begin{array}{l}\text { orchards, vineyards, row crops, } \\
\text { dairies, and other animal } \\
\text { operations typical of the San } \\
\text { Joaquin Valley }\end{array}$ & $\begin{array}{l}\text { representative of the complex, } \\
\text { multi-crop systems found in } \\
\text { irrigated agricultural settings } \\
\text { of the arid western USA }\end{array}$ \\
\hline $\begin{array}{l}\text { Depth to water, minimum } \\
\text { and maximum at time of } \\
\text { sampling }(\mathrm{m})\end{array}$ & $0-11$ & $3-22$ & $5-10$ & $0-14$ \\
\hline Mean annual precipitation $(\mathrm{cm})$ & 112 & 68.5 & 31.0, highly variable & 18.5 \\
\hline $\begin{array}{l}\text { Surficial material; recharge } \\
\text { rates }\left(\mathrm{cm} \mathrm{yr}^{-1}\right) \dagger\end{array}$ & sandy loam, 31.5 & $\begin{array}{l}\text { loess where cultivated, } \\
\text { sandy where incised, } 5.2\end{array}$ & dune sand, 42.2 & $\begin{array}{l}\text { stratified fine sand and silt, } \\
11.9\end{array}$ \\
\hline Aquifer material & sand and some silty lenses & sand and gravel & $\begin{array}{l}\text { alluvial sediment and } \\
\text { fluvial materials }\end{array}$ & silt to gravel \\
\hline Ground water age & $\begin{array}{l}\text { recharged within the last } \\
10-20 \mathrm{yr}\end{array}$ & $\begin{array}{l}\text { shallow recharged } \\
\text { within the last } 10-20 \mathrm{yr} \text {, } \\
\text { deeper up to } 40-50 \mathrm{yr}\end{array}$ & up to $30 \mathrm{yr}$ & $<5$ to $>50 \mathrm{yr}$ \\
\hline Agricultural cropping pattern & $\begin{array}{l}\text { alternating corn and } \\
\text { soybeans }\end{array}$ & $\begin{array}{l}\text { alternating corn and } \\
\text { soybeans; irrigation } \\
\text { used to augment } \\
\text { precipitation shortfall }\end{array}$ & $\begin{array}{l}\text { irrigated almond orchards, feed } \\
\text { corn, and variety of truck crops }\end{array}$ & $\begin{array}{l}\text { irrigated grapes, fruit } \\
\text { orchards, and feed corn }\end{array}$ \\
\hline $\begin{array}{l}\text { Irrigation type and } \\
\text { amount }(\mathrm{cm}) \neq\end{array}$ & none & center-pivot sprinkler, 25.4 & $\begin{array}{l}\text { sprinkler, } 107 \\
\text { rill, undetermined }\end{array}$ & $\begin{array}{l}\text { sprinkler, undetermined } \\
\text { rill, } 74\end{array}$ \\
\hline $\begin{array}{l}\text { Pesticide, rate }\left(\mathrm{kg} \mathrm{ha}^{-1}\right) \text {, } \\
\text { date applied } \neq\end{array}$ & none & $\begin{array}{l}\text { atrazine, } 0.90 \text { on } 9 \text { May } \\
\text { and } 1.12 \text { after planting; } \\
\text { metolachlor, } 0.67 \text { on } 9 \\
\text { May; chlorpyrifos, } 0.56 \\
\text { on } 5 \text { July }\end{array}$ & $\begin{array}{l}\text { simazine, } 0.25 \text { on } 23 \text { Apr. and } \\
24 \text { Dec.; } 2,4-D \text { dimethylamine } \\
\text { salt, } 1.9 \text { on } 23 \text { Apr. and } 0.5 \text { on } 24 \\
\text { Dec.; trifluralin, } 1.0 \text { on } 16 \text { July; } \\
\text { chlorpyrifos, } 1.1 \text { on } 29 \text { June }\end{array}$ & $\begin{array}{l}\text { see Capel et al., } 2008 \text { for } \\
\text { pesticide applications in } \\
\text { Granger Basin }\end{array}$ \\
\hline
\end{tabular}

† Modified from Green et al. (2008).

キ Modified from Hancock et al. (2008).

computed using a piston-flow model using a single age tracer at the MD, NE, and CA sites. At the WA site, apparent ages were estimated using a multiple-tracer analysis (Green et al., 2008). All techniques and instruments used for sampling and chemical analysis complied with standard U.S. Geological Survey protocols (USGS, 2007), which allowed for comparison of the data among the study sites. Additional information on the methods of sampling and chemical analysis is reported by Capel et al. (2008).

The pesticide degradate fraction (Eq. [1], hereafter referred to as "fraction") computed for a given pesticide degradate represents the ratio of the molar concentration of the degradate (e.g., metolachlor ESA) [2-[(2-ethyl-6-methylphenyl)(2-methoxy-1methylethyl)amino]-2-oxoethanesulfonic acid] to the sum of the molar concentrations of its parent pesticide (e.g., metolachlor) and all of the $n$ degradates ( $n=2$ for metolachlor and 1 for atrazine) of the parent pesticide for which analyses were conducted (e.g., metolachlor ESA and metolachlor OXA) [2-[(2-ethyl-6methylphenyl)(2-methoxy-1-methylethyl)amino]-2-oxoacetic acid]. The fraction can therefore range from zero (degradate of interest not detected) to 1 (neither the parent nor any of its other degradates detected, only the degradates of interest). No fraction was calculated if neither parent nor degradate(s) were detected. For the purpose of calculating the fractions for atrazine and deethylatrazine, when atrazine was detected without deethylatrazine (or vice versa), the concentration of the nondetected compound was set to its laboratory reporting level. This was done because the concentrations of atrazine and deethylatrazine were often close to the laboratory reporting levels, and the substitution gave more representative fractions. No such substitutions were made for nondetected compounds if neither atrazine nor deethylatrazine were detected. For the other parent compound (e.g., metolachlor), the molar concentrations of degradates were often much greater than those for the parents, so substitution had only a minor effect on the computed fraction.

Fraction of degradate $i=$

$$
\left[\text { Degradate }_{\mathrm{i}}\right] /\left([\text { Parent }]+\sum_{j=1}^{\mathrm{n}}\left[\text { Degradate }_{j}\right]\right)[1]
$$

Calculation of fractions for atrazine and deethylatrazine required "correction" of analytical results to account for significant differences in analytical recovery for the two analytes. The median recovery of atrazine in laboratory reagent-water spike samples during 2004 was 104\%, whereas median recovery of deethylatrazine was $38 \%$. Concentrations of atrazine and deethylatrazine in ground water samples were corrected to estimate $100 \%$ recovery using these median recoveries before calculation of the fraction of deethylatrazine.

\section{Results}

\section{Flow Systems}

Four sites in diverse agricultural landscapes in MD, NE, CA, and WA were selected for study (Fig. 1, Table 1). The sites differed 
in land use, crops grown, climate, agricultural practices, irrigation, geohydrologic settings, and redox conditions (Capel et al., 2008). The ground water was oxic at the MD site and generally oxic at the WA site, whereas the water at the NE and CA sites varied from oxic to anoxic. In 2004, the maximum depths to water in the four flow systems were (from east to west) about $11 \mathrm{~m}$ in MD, $22 \mathrm{~m}$ in $\mathrm{NE}, 10 \mathrm{~m}$ in CA, and $14 \mathrm{~m}$ in WA (Table 1). Additional details regarding the four sites and their environmental settings are provided by Fredrick et al. (2006), Gronberg and Kratzer (2006), Hancock and Brayton (2006), Payne et al. (2007), and Capel et al. (2008). The annual amounts of pesticides used and application rates for each site are also reported by Capel et al. (2008).

At the MD site, agricultural production was dominated by corn and soybeans, which typically are grown in alternating years, and small grain crops. Taken together, these comprised $60 \%$ of the primary crops (Capel et al., 2008). Of the targeted pesticides, triazine and chloroacetanilide herbicides were the most widely used. The ground water flow system at this site derives all of its recharge from precipitation. Here, infiltrating water moves through the sandy UZ to the shallow ground water where it eventually discharges into Morgan Creek. During the sampling period in May 2004, depths to the water table varied from $11 \mathrm{~m}$ near recharge areas to zero (i.e., coincident with land surface) near Morgan Creek (Table 1). The surficial aquifer is primarily sandy with some silty lenses, and all wells were completed within the sand. Ground water age dating indicated that the water at the MD site is some of the youngest water sampled from any of the four study sites (Green et al., 2008) (Fig. 1A). Most of the water within this flow system has recharged within the past $20 \mathrm{yr}$. Plentiful precipitation $\left(112 \mathrm{~cm} \mathrm{yr}^{-1}\right)$ and well drained soils contribute to the fact that the MD flow system was the only one of the four systems studied in which all of the ground water sampled was oxic $\left(\mathrm{O}_{2}>0.59 \mathrm{mmol} \mathrm{L}^{-1}\right.$ in all samples).

At the NE site, similar to MD, corn and soybeans typically are grown in alternating years and dominate agricultural production (100\% of the primary crops) (Capel et al., 2008). Also similar to $\mathrm{MD}$, triazine and chloroacetanilide herbicides were the most widely used of all the targeted pesticides. At the NE site, the crop water demand is satisfied primarily through precipitation; however, as is common throughout the Maple Creek Basin, ground water irrigation is used to offset shortages in precipitation, and one field at the study site is irrigated with ground water. The primary regional ground water flow direction at this site, unlike the other three, does not parallel the transect of wells. Rather, the ground water flows at an angle between 70 and 90 degrees to the orientation of the transect of wells. The ground water flow system at this site is the deepest (about $22 \mathrm{~m}$ ) of the four sites, and the deepest parts of the system underlie 7 -m-thick loess deposits. These deposits are the surface on which most crops are grown at this study site (Fig. 1B). The NE site has some of the oldest ground water of the four study sites. The water in the shallowest part of the flow system has recharged within 10 to $20 \mathrm{yr}$; however, the deeper parts of the flow system contain water that recharged in the early 1950 s to mid-1960s. Therefore, somewhere between the shallowest and intermediate-depth or deepest flow-system wells, a transition zone likely exists where the local flow system that moves water from the agricultural fields to Maple Creek intermixes with the upper part of the regional flow system. The water in this flow system, which was recharged more than $50 \mathrm{yr}$ ago and could not be dated with the techniques used in this study, flows through the study site and discharges at remote locations. Anoxic water was detected in samples from the deepest wells at sites N22 and N21 and in all wells at N20 (Fig. 1B), and oxic water was detected at the top of the flow system where an influx of recharge water from ground water irrigation occurs. Consequently, the oxic area contained most of the atrazine and one of the two metolachlor detections (the other was at N20r, where infiltration of surface water due to an increased hydraulic gradient during high water in Maple Creek before the sampling may have been the source of the metolachlor).

The CA site is within the San Joaquin Valley. At this site, crops include almond orchards, feed corn (grown on a nonrotational basis), and a wide variety of truck crops (e.g., vegetables and fruits such as strawberries). Plant water demand is satisfied exclusively by irrigation from canals carrying diverted streamflow or ground water. This area of CA uses a large number of pesticides, including insecticides and fungicides (Capel et al., 2008). Insecticides typically are sprayed aerially in orchards or applied directly to vegetable fields. The site chosen for the ground water flow system study is typical of areas in California dominated by deciduous orchards, and a wide variety of truck crops are grown in the area. Recharge of the ground water system is dominated by infiltration from irrigation and supplemented by precipitation. Recharge occurs primarily at the land surface but also as subsurface inflow from upgradient areas (Gronberg and Kratzer, 2006). The surficial aquifer consists of alluvial sediment interspersed with fluvial materials and overlain by dune sand. The surficial aquifer overlies an 18-m-thick confining unit. The flow-system wells are open primarily in sediment ranging in texture from silty sand to gravel layers. Ground water age dates (based on estimates derived from chlorofluorocarbon and sulfur hexafluoride analyses) indicate that the water in these wells was recharged within the last $30 \mathrm{yr}$. Ground water conditions in the central part of the flow system (well nest C21 in Fig. 1C) were oxic, whereas the upper and lower parts of the flow system were anoxic. The likely cause of the oxic conditions is a greater rate of recharge in the middle of the flow system due to the presence of a flood-irrigated corn field.

The WA site (Fig. 1D) is located in arid south-central Washington State. Crops grown include grapes, fruit orchards, and feed corn that are grown on a nonrotational basis. A large number of pesticides, including insecticides and fungicides, are used in this area of WA (Capel et al., 2008). The fields to which triazine and chloroacetanilide herbicides typically were applied account for $42 \%$ of the primary crops in Granger Drain Basin (Capel et al., 2008). The ground water flow system at this site is recharged primarily by infiltrating irrigation water delivered by canals. Meager precipitation (typically about $18.5 \mathrm{~cm} \mathrm{yr}^{-1}$ ), most of which falls in winter, contributes a small portion of the total recharge (Payne et al., 2007). Recharge takes place in the northern part of the study site and along the crests of northeast-southwest trending ridges that dissect the watershed (Payne et al., 2007). Ground water discharge is primarily to small agricultural drains on the valley floor, although deeper ground water ultimately discharges to the Yakima River. The upper $10 \mathrm{~m}$ of the surficial aquifer consists of stratified fine 
sand and silt. In general, the underlying aquifer material is coarser and more permeable than the surficial aquifer but is spatially heterogeneous, ranging in size from silt to gravel. Ground water varies from oxic to anoxic. The apparent age of ground water at this site ranged from less then $5 \mathrm{yr}$ to greater than $50 \mathrm{yr}$. The apparent age of ground water generally increases with distance from recharge areas and with depth in the aquifer.

\section{Occurrence of Pesticides}

Pesticides were detected in ground water ( 59 wells were sampled) and in the aquifer solids (29 sediment cores analyzed from the well-screen locations). The median of the sum of the concentrations of pesticides analyzed in ground water (aqueous) samples (flow-system wells only) differed greatly among study sites, with the highest concentrations detected at the $\mathrm{MD}$ site and the lowest at the WA site (MD: $35.2 \mathrm{nmol} \mathrm{L}^{-1}[N=9]$; NE: 2.14 $\times 10^{-1} \mathrm{nmol} \mathrm{L}^{-1}[N=12]$; CA: $6.05 \times 10^{-1} \mathrm{nmol} \mathrm{L}^{-1}[N=12]$; WA: $<0.097 \mathrm{nmol} \mathrm{L}^{-1}[N=13]$ ). Quality assurance samples (replicates) generally varied from about 2 to $27 \%$. The largest variations were on the estimated constituents (e.g., those near the laboratory reporting level). Forty-five parent pesticides and 40 degradates were analyzed from water samples, and 42 parent pesticides and 25 degradates were analyzed from aquifer solids. Of this group, only five parent pesticides and their degradates were detected frequently; these five pesticides were from two classes: triazines (atrazine, simazine) and chloroacetanilides (acetochlor, alachlor, and metolachlor). The frequency of detection of these five compounds is consistent with that reported in ground water nationally by Gilliom et al. (2006). Seven pesticides or pesticide degradates were detected in more than 10 samples from the flow-system network: metolachlor ESA at 29, deethylatrazine at 24, alachlor ESA [2-([2,6-diethylphenyl] methoxymethylamino)-2-oxoethanesulfonic acid] at 18 , atrazine at 17 , metolachlor OXA at 14 , simazine at 14 , and metolachlor at 12 . Of these seven compounds, the top three, and four of the top five, most frequently detected compounds were degradates. Other compounds detected in ground water included metribuzin [4-amino-6-(1,1-dimethylethyl)-3(methylthio)-1,2,4-triazin-5(4H)-one], acetochlor, acetochlor ESA [2-([2-methyl-6-ethylphenyl]ethoxymethylamino)-2-oxoethanesulfonic acid], acetochlor OXA [2-([2-methyl-6-ethylphenyl] ethoxymethylamino)-2-oxoacetic acid], acetochlor/metolachlor ESA, secondary amide [2-([2-ethyl-6-methylphenyl]amino)-2oxoethanesulfonic acid], alachlor, alachlor OXA [2-([2,6-diethylphenyl]methoxymethylamino)-2-oxoacetic acid], and alachlor sulfinylacetic acid [2-([2,6-diethylphenyl]methoxymethylamino)2-oxoethanesulfonic acid]. Although not detected in ground water samples, 3,4-dichloroaniline, a degradate of several phenylurea herbicides including diuron [ $\mathrm{N}^{\prime}$-(3,4-dichlorophenyl)-N,Ndimethylurea] and linuron [ $\mathrm{N}^{\prime}$-(3,4-dichlorophenyl)-N-methoxy$\mathrm{N}$-methylurea], was detected in one aquifer sediment sample from the CA study site.

The occurrence of parent pesticides in ground water depends on a number of factors, including their physicochemical properties (most importantly $\mathrm{K}_{\mathrm{oc}}$ and soil dissipation half-life $\left[\mathrm{t}_{1 / 2, \text { soil }}\right]$ ), amount and rate of use, agricultural management practices, and amount and intensity of rainfall/irrigation. For the subset

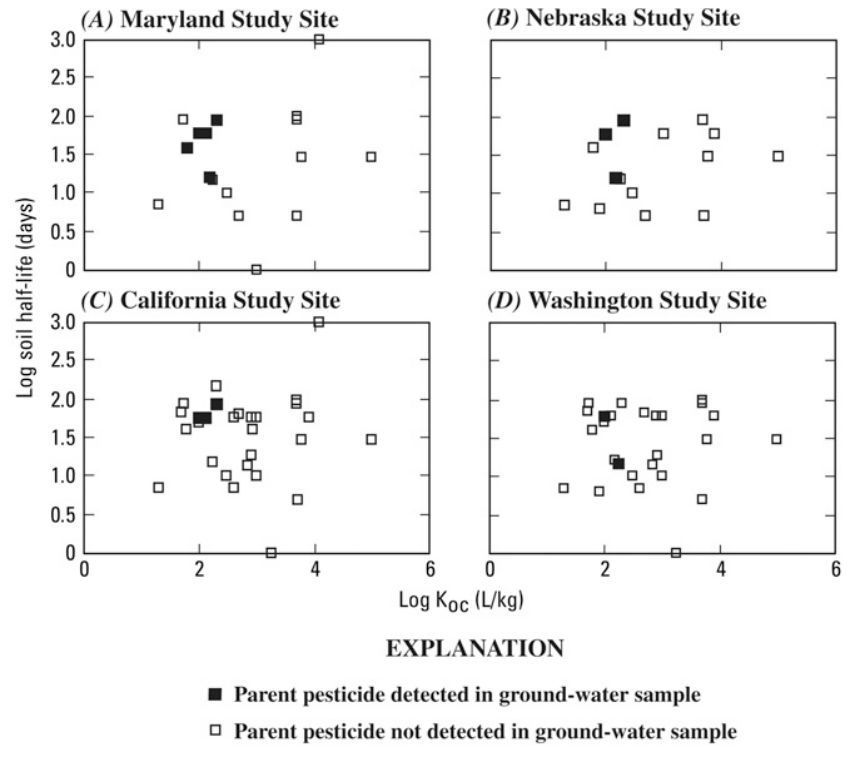

Fig. 2. Occurrence of the subset of parent pesticides used in each of the watersheds as a function of chemical properties (A) Maryland, (B) Nebraska, (C) California, and (D) Washington.

of pesticides used in each of the flow-system areas, Fig. 2 shows their occurrence as a function of its $\log \mathrm{K}_{\mathrm{oc}}$ and $\log \mathrm{t}_{1 / 2, \text { soil }}$. Ten of the 14 parent pesticides that were detected in these four ground water systems fall in the upper left quadrant of the graphs (Fig. 2), which represents pesticides that have long $t_{1 / 2, \text { soil }}$ and small $\mathrm{K}_{\mathrm{oc}}$ values, as expected. The remaining four were in the lower left quadrant, which represents pesticides that have small $\mathrm{t}_{1 / 2, \text { soil }}$ and small $\mathrm{K}_{\text {oc }}$ values.

Lysimeters, installed at shallow depths above some of the flowsystem wells, were sampled concurrently, or nearly so, with the flow-system wells. The same pesticides and pesticide degradates were detected in many samples from sites having a deep UZ lysimeter and a shallow ground water well. Common compounds among the UZ (Hancock et al., 2008) and shallow ground water samples are limited to triazine and chloroacetanilide herbicides and their degradates. At one site in NE, concentrations of atrazine and deethylatrazine in the samples collected from the lysimeters were as much as 100 times greater than concentrations in the underlying ground water. At MD, metolachlor ESA and metolachlor OXA were detected in the three deepest UZ locations and always at concentrations similar in magnitude to the underlying shallow ground water. Conversely, alachlor ESA only was detected in one of the deep UZ samples and atrazine and deethylatrazine were not detected in any of the deepest UZ samples. At the NE site, metolachlor ESA and metolachlor OXA were detected in all three deep UZ locations, and alachlor ESA was detected in two of the three deepest UZ locations. Metolachlor ESA and alachlor ESA were detected in the underlying shallow ground water at two of the three sites and were always detected together. In WA, metolachlor and alachlor OXA were detected in the deepest UZ sample, whereas no pesticides were detected in the underlying shallow ground water. In CA, no pesticide detections were observed in the deepest $\mathrm{UZ}$.

Seven pesticides or pesticide degradates detected in deep UZ samples (Hancock et al., 2008) were not detected in shallow 

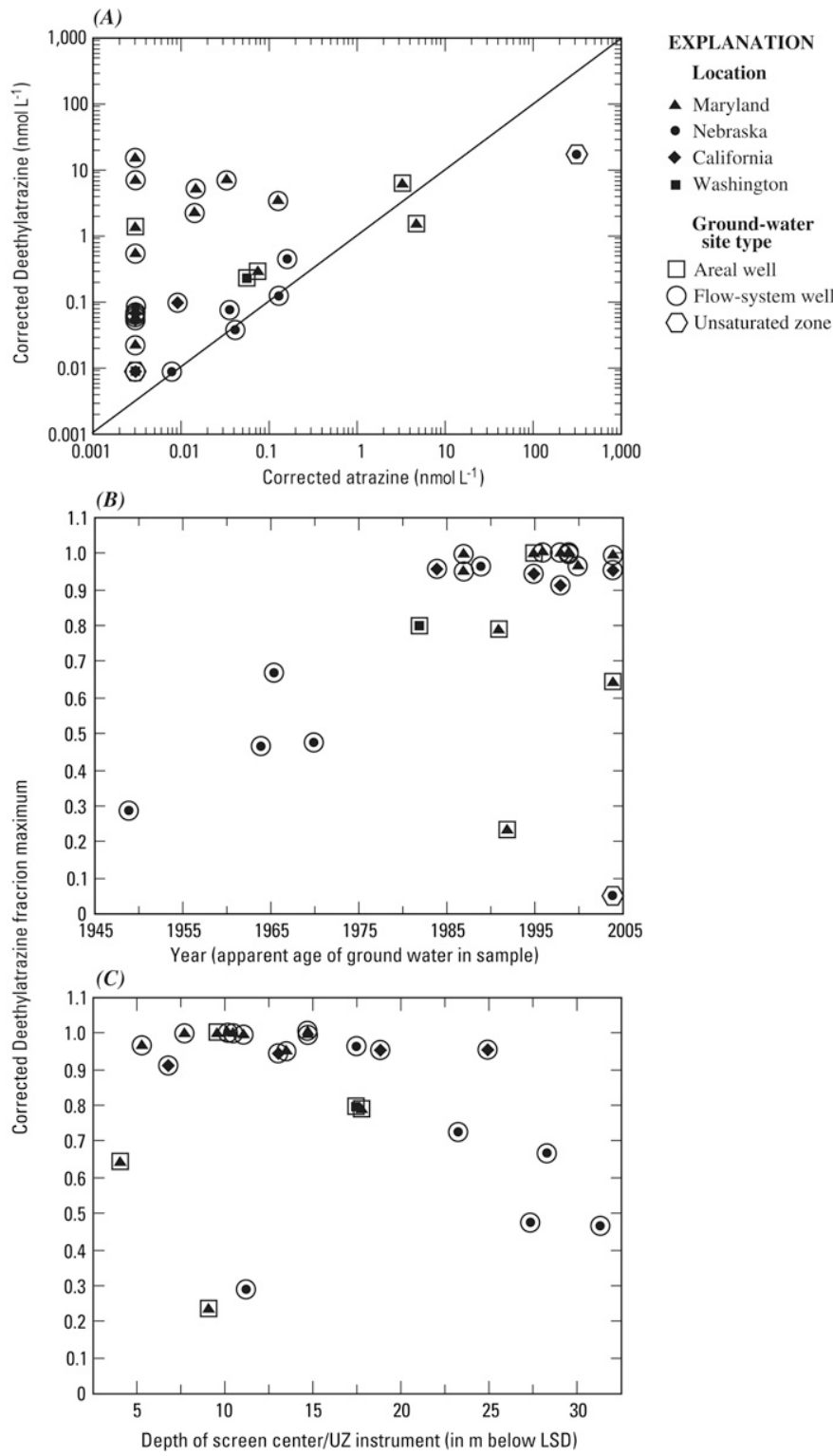

Fig. 3. Bivariate plots of corrected deethylatrazine relative to (A) corrected atrazine, (B) age of ground water, and (C) depth of screened interval (atrazine and deethylatrazine corrected for recovery). The laboratory reporting level divided by $10\left(3.2 \times 10^{-3} \mathrm{nmol} \mathrm{L}^{-1}\right)$ was substituted for a nondetected value so the data point would plot on the log-log plot (A); this value indicates no atrazine was present in the sample while deethylatrazine was present.

ground water samples. These compounds included one insecticide (chlorpyrifos [O,O-diethyl O-(3,5,6-trichloro-2-pyridinyl) phosphorothioate]), two insecticide degradates of fipronil (desulfinyl fipronil amide and fipronil sulfone), and four herbicides (dacthal [dimethyl 2,3,5,6-tetrachlorobenzene-1,4dicarboxylate], prometon [6-methoxy-N,N'-bis(1-methylethyl)-1,3,5-triazine-2,4-diamine], tebuthiuron [N-[5-(1,1-dimethylethyl)-1,3,4-thiadiazol-2-yl]$\mathrm{N}, \mathrm{N}^{\prime}$-dimethylurea], and trifluralin [2,6-dinitro-N,N-dipropyl4-(trifluoromethyl)benzenamine]). Two pesticides detected below the water table were not detected in samples from any deep UZ samples (3,4-dichloroaniline in sediment samples at the CA study site and metribuzin from water samples at the MD study site).
In ground water, atrazine or its degradation product deethylatrazine were detected in about one half of the wells across all four study areas but infrequently at the WA site. Atrazine and deethylatrazine were detected together in ground water samples from the MD and NE study sites (Fig. 3A) and more frequently than in water samples from the other two sites. This may be due in part to the long-term, homogeneous nature of the corn-soybean cropping that characterizes these two study sites. Atrazine was detected in samples from all shallow flow-system wells at the MD study site but was detected in only one of six samples from wells deeper than $15 \mathrm{~m}$. Atrazine and/or deethylatrazine was detected in the oldest water age dated (1949) (Fig. 3B) to recent and in the shallowest to deepest wells (Fig. 3C). Atrazine concentration generally decreased with depth or was not detected. Conversely, deethylatrazine was detected in all flow-system wells at the MD study site (except one) and at concentrations commonly one or two orders of magnitude greater than atrazine. At the NE site, deep wells directly beneath the corn field had smaller concentrations of atrazine and deethylatrazine than their associated shallower well. At the CA site, atrazine was detected only in water samples from the shallowest and deepest wells of the cluster at the terminal end of the flow system, whereas deethylatrazine also was detected in the sample from the shallowest well at the same location. Atrazine and deethylatrazine were detected only in two areal wells in samples from the WA site, both of which had detections of each. Overall, atrazine and/or its degradate deethylatrazine were present in most of the study areas, and these compounds were present in ground water that was old to recent and shallow to deep.

Concentrations of atrazine varied from $0.008 \mathrm{nmol} \mathrm{L}^{-1}$ (estimated; e.g., below the laboratory reporting level [Childress et al., 1999] of $0.0325 \mathrm{nmol} \mathrm{L}^{-1}$ ) to $5.1 \mathrm{nmol} \mathrm{L}^{-1}$, with the largest concentration in water from the areal wells at the MD study site. Concentrations of deethylatrazine ranged from $0.014 \mathrm{nmol} \mathrm{L}^{-1}$ (estimated; below the laboratory reporting level of $0.032 \mathrm{nmol}$ $\left.\mathrm{L}^{-1}\right)$ to $5.5 \mathrm{nmol} \mathrm{L}^{-1}$, with the largest concentrations detected in flow-system wells at the MD study site. Deethylatrazine concentrations ranged from 0.020 to $5.5 \mathrm{nmol} \mathrm{L}^{-1}$ in ground water samples from MD, NE, and CA in which the parent compound atrazine was not detected. In contrast, only one sample from the NE site at $0.008 \mathrm{nmol} \mathrm{L}^{-1}$ and one sample from the CA site at $0.028 \mathrm{nmol} \mathrm{L}^{-1}$ had detectable concentrations of atrazine but no deethylatrazine. At the MD site, the relative frequency of detection of atrazine compared with the detection of deethylatrazine in the ground water was in part a function of well depth (Fig. 3C). All other samples from the CA site containing deethylatrazine were from wells in the middle cluster. Atrazine was not detected in samples from these wells; however, simazine, which dealkylates to form deisopropylatrazine but not deethylatrazine, was detected in wells where deethylatrazine was detected but atrazine was not.

Metolachlor and its degradation products, metolachlor ESA and/or metolachlor OXA, were detected in about one half of all wells sampled (metolachlor, 12 detections in 59 samples; metolachlor ESA, 29 detections; and metolachlor OXA, 15 detections), excluding those at the WA site. Metolachlor was al- 
ways detected with metolachlor ESA and/or metolachlor OXA, excluding one sample at the NE site. When metolachlor was concomitant with metolachlor ESA and/or metolachlor OXA, metolachlor had one to four orders of magnitude smaller concentrations. Metolachlor, which was detected at concentrations up to $0.37 \mathrm{nmol} \mathrm{L}^{-1}$ in $64 \%$ of ground water samples from the MD site, was detected in $13 \%$ of samples from the NE site (including a sample from one well possibly affected by stream infiltration) and in $8 \%$ of samples from the CA site. Metolachlor was present at concentrations that were generally two to three orders of magnitude less than metolachlor ESA or metolachlor OXA. Metolachlor ESA, with concentrations as high as $46 \mathrm{nmol} \mathrm{L}^{-1}$, was the most frequently detected compound. Whenever metolachlor was detected, except for one sample from the NE site, metolachlor ESA also was detected. Metolachlor ESA generally was present at the largest concentrations in samples from the MD site, where it was detected in all but one sample. Metolachlor ESA was detected in $47 \%$ of the samples from the NE site and in $75 \%$ of the samples from the CA site. Metolachlor OXA concentrations generally were smaller than those of metolachlor ESA (Fig. 4A). Metolachlor OXA was detected in $73 \%$ of the samples from the MD site, in only $7 \%$ of the samples from the NE site (even though it frequently was detected in the UZ above ground water sampling sites [Hancock et al., 2008]), and in $25 \%$ of the samples from the $\mathrm{CA}$ site. Excluding the near-stream site at NE, most samples that contained more metolachlor parent compound than metolachlor ESA were collected from wells where the apparent ground water age was younger than about 1993 (Fig. 4B) and whose depths were less than $15 \mathrm{~m}$ (Fig. 4C). Overall, metolachlor ESA was the most common pesticide detected in water samples. When its parent compound, metolachlor, was detected, with one exception, it always was detected with the ESA degradate.

Alachlor, whose use has diminished substantially in the last decade (Fig. 5A), was detected only once as the parent compound along with one detection each of its OXA and sulfinylacetic acid (SAA) degradates; however, the ESA degradate of alachlor was detected in 18 of the 59 wells ( $31 \%$ of the samples). Most of the detections of alachlor ESA at the MD and NE study sites occurred in the same samples where metolachlor ESA was detected, and frequently alachlor ESA was detected with deethylatrazine. At the MD site, all occurrences of alachlor ESA were concomitant with metolachlor ESA. At the NE site, alachlor ESA was limited primarily to those flow-system wells underlying or directly adjacent to the corn field, which also had concentrations of atrazine, deethylatrazine, and metolachlor ESA. Finally, acetochlor, a chloroacetanilide herbicide registered for use in 1994, was probably detected infrequently because its use was restricted to corn, it had not been widely used in the study basins (Capel et al., 2008), and the estimated recharge dates for most wells sampled in the study pre-date the first uses of this compound nationally. Acetochlor was detected in one sample from the NE site, whereas its degradates acetochlor ESA and acetochlor OXA were detected two times each—acetochlor ESA in MD and WA samples and acetochlor OXA in NE and WA samples.

Few concentrations of pesticides in aquifer sediment have been reported in the literature. Pesticides were detected in
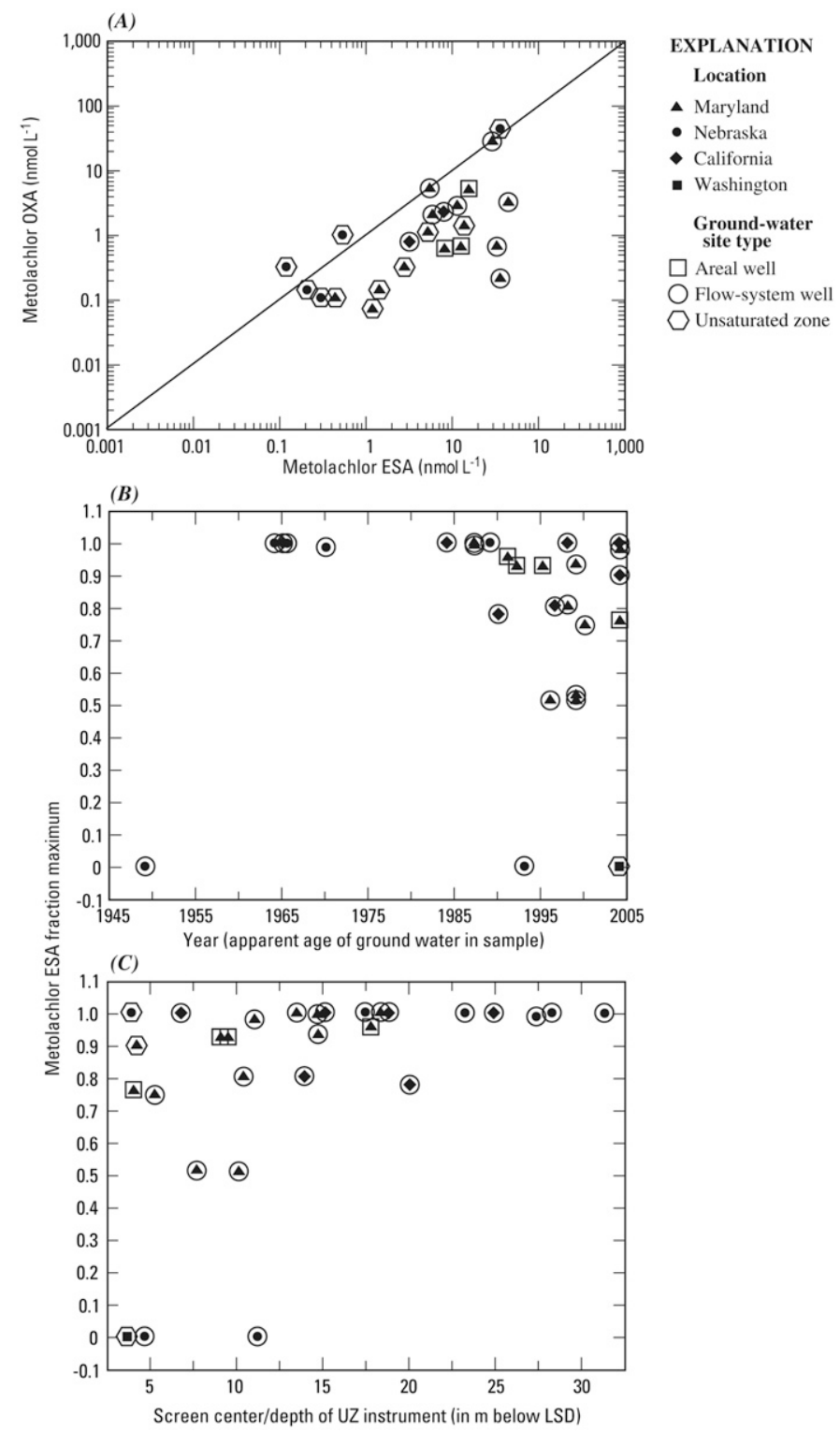

Fig. 4. Bivariate plots of metolachlor ethanesulfonic acid (ESA) as a function of (A) metolachlor oxanilic acid (OXA), (B) age of ground water, and (C) depth of screened interval. " 0 " indicates no metolachlor ESA is present while other related compounds (either metolachlor and/or metolachlor OXA) are present.

aquifer sediment in 10 of the 29 wells (MD: 7; CA: 2; WA: 1). Five different pesticides or degradates were detected in the aquifer sediment-3,4-dichloroaniline, atrazine, deethylatrazine, metolachlor, and simazine. Of these, atrazine and deethylatrazine were identified only in aquifer sediment from the MD site. Simazine was identified in aquifer sediment from the CA and WA sites, and metolachlor was identified in aquifer sediment from the MD and CA sites. With one exception, all pesticides detected in aquifer sediments also were detected in water samples collected from the same site. At that one site (MD), simazine was detected in aquifer sediment but not in ground water; however, simazine was reported to have been applied to the field in 2002 when corn was last grown. Concentrations of atrazine and deethylatrazine ranged from 
(A)

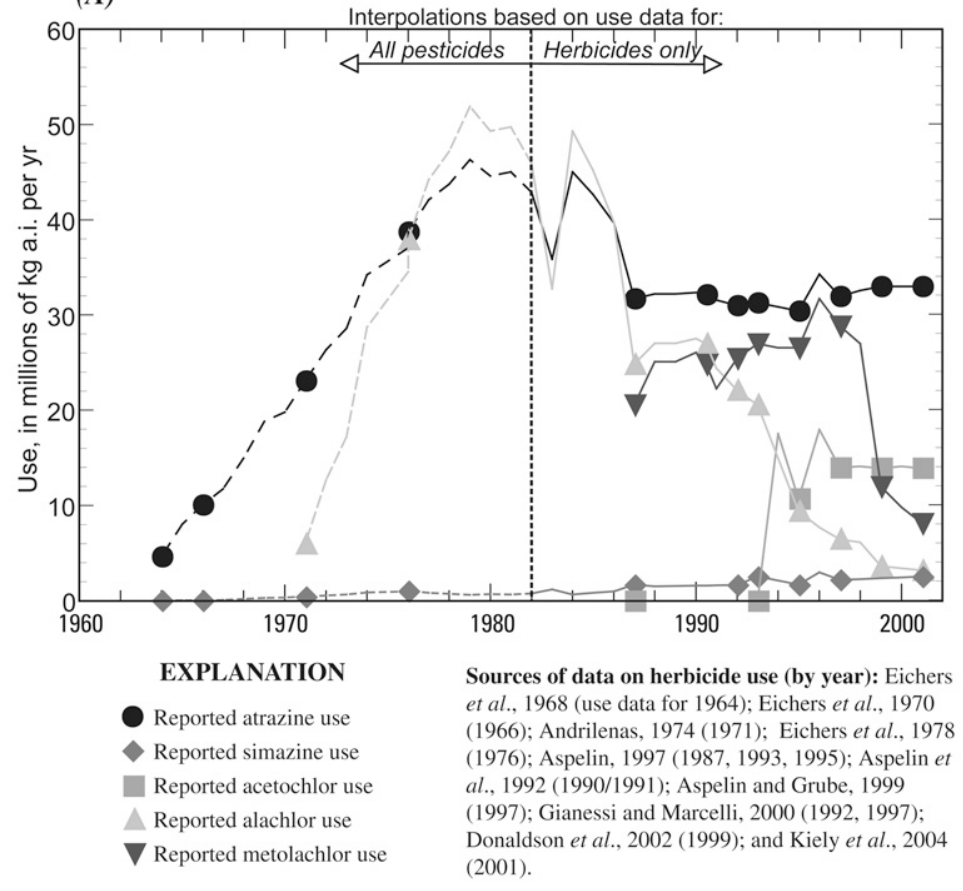

(B)

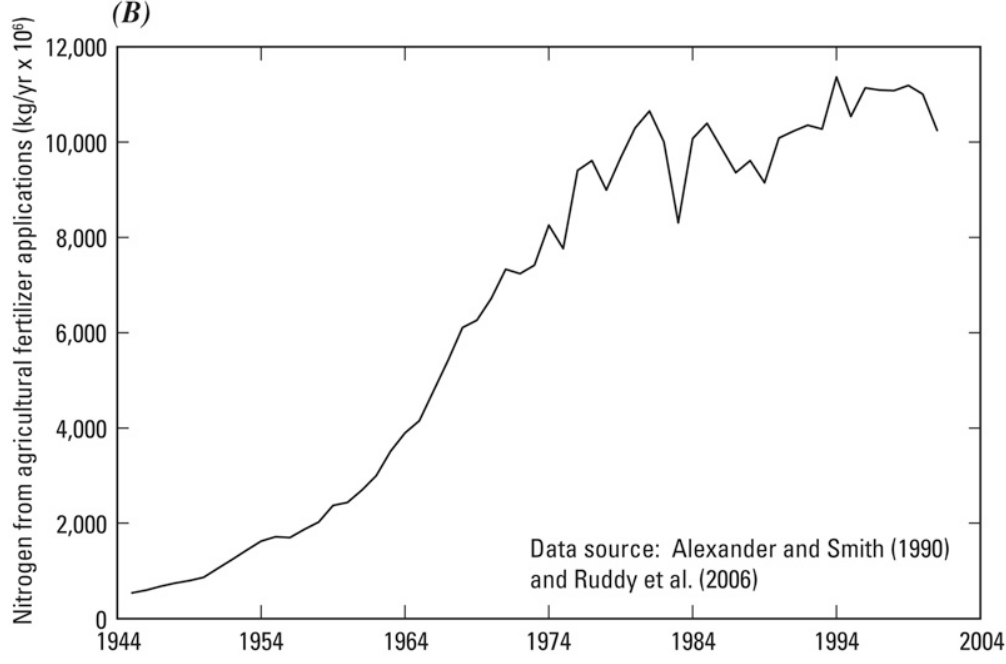

Fig. 5. Graphs showing use of $(A)$ herbicides in agricultural settings and (B) nitrogen fertilizer in the conterminous USA. Interpolations before 1982 in (A) are based on use data for all pesticides; interpolations from 1982-2001 use data for all herbicides.

0.5 to 0.7 and 0.7 to $1.8 \mu \mathrm{g} \mathrm{kg}^{-1}$ (dry wt), respectively, and concentrations of simazine and metolachlor ranged from 0.3 to 1.7 and 0.4 to $0.9 \mu \mathrm{g} \mathrm{kg}^{-1}$ (dry wt), respectively. The single detection of 3,4-dichloroaniline was $0.17 \mu \mathrm{g} \mathrm{kg}^{-1}$ (dry wt).

\section{Relations among Pesticide Concentrations and Redox Conditions in the Aquifer}

Concentrations of seven of eight pesticides detected five or more times in ground water were significantly correlated $(\alpha=$ 0.05 ) with two or more indicators of redox conditions in the aquifer (Table 2). Principal components analysis and stepwise logistic regression were used to explore relations among the redox indicators and to identify those indicators that explained the greatest amount of variance in the pesticide data. In both analyses, apparent age, $\mathrm{O}_{2}$, and excess nitrogen gas $\left(\mathrm{N}_{2}\right)$ were determined to be important indicators of the presence and concentration of pesticides in these ground water systems.

Three distinct types of water were identified at the four study sites on the basis of these three indicators and the total concentration of pesticides at each site (Fig. 6). Samples plotting in region I were characterized by $\mathrm{O}_{2}$ concentrations greater than about $0.10 \mathrm{mmol} \mathrm{L}^{-1}$ and excess $\mathrm{N}_{2}$ concentrations less than about $0.076 \mathrm{mmol}$ $\mathrm{L}^{-1}$, indicating that little or no denitrification has taken place. The median age of these samples was $8 \mathrm{yr}$, the youngest water of the three regions on the graphs. The oldest sample in this region was 23 yr. Region I samples had consistently high concentrations of agricultural pesticides (median concentration, $14.9 \mathrm{nmol} \mathrm{L}^{-1}$ ), and $89 \%$ contained one or more detectable pesticides (median, 4.5). The oldest $50 \%$ and the youngest $50 \%$ of the region I samples contained similar pesticide concentrations and similar number of detections per sample, indicating that aerobic degradation of pesticides is not a significant factor in these study areas. Metolachlor and metolachlor ESA concentrations were slightly larger in the older group of region I samples and may reflect the reduced loading of metolachlor after the introduction of S-metolachlor around 2000. Alachlor ESA concentrations were also larger in the older sample group, which may reflect the reduced use of alachlor since the introduction of acetochlor in 1994 (National Agriculture Statistics Service, 2006) and, more recently, the introduction of glyphosate-tolerant [N-(phosphonomethyl) glycine] crops.

Samples plotting in region II had $\mathrm{O}_{2}$ concentrations less than about $0.03 \mathrm{mmol} \mathrm{L}^{-1}$ and excess $\mathrm{N}_{2}$ concentrations greater than about $0.125 \mathrm{mmol} \mathrm{L}^{-1}$. The low $\mathrm{O}_{2}$ concentrations and buildup of $\mathrm{N}_{2}$ gas are consistent with nitrate-reducing conditions in the aquifers. On average, region II samples were older (median age, 23 yr) than samples in region I and ranged in age from 8 to $45 \mathrm{yr}$. Eighty-six percent of samples from region II contained one or more pesticides (median, 3), which is similar to pesticide occurrence at sites plotting in region I. The median pesticide concentration among these samples, however, was $0.53 \mathrm{nmol} \mathrm{L}^{-1}$ —more than an order of magnitude less than samples from region I. It is possible that the differences in pesticide concentrations between these two geochemically distinct regions are due to degradation under anaerobic conditions. This possibility also is supported by data for those wells plotting in regions I and II in which the age of the water was $15 \mathrm{yr}$ or less. In this subset of wells, smaller concentrations of pesticides were detected in samples in which nitrite also was detected. Nitrite is an intermediate product formed during denitrification (Betlach and Tiedje, 1981; Smith et al., 2004) and typically is unstable in aquifers under reducing conditions. Its presence is an indicator of active denitrification. The data set is not suited to further testing 
Table 2. Correlation (Spearman's rho) between pesticides detected in ground water and indicators of redox conditions.

\begin{tabular}{|c|c|c|c|c|c|c|c|c|}
\hline & No. of samples & No. of detections & Apparent age & $\begin{array}{l}\text { Depth of screened interval } \\
\text { below water table }(\mathrm{m})\end{array}$ & Dissolved $\mathrm{O}_{2}$ & $\begin{array}{c}\mathrm{NH}_{3}{ }^{-}-\mathrm{N}, \\
\text { filtered }\end{array}$ & $\begin{array}{l}\mathrm{NO}_{2}^{-}-\mathrm{N}, \\
\text { filtered }\end{array}$ & $\begin{array}{c}\left(\mathrm{NO}_{2}{ }^{-}+\mathrm{NO}_{3}{ }^{-}\right)-\mathrm{N}, \\
\text { filtered } \\
\end{array}$ \\
\hline Metolachlor ESA† & 59 & 29 & $0.45 \neq$ & -0.02 & 0.36 & -0.08 & -0.14 & 0.37 \\
\hline Deethylatrazine & 59 & 24 & 0.49 & -0.24 & 0.55 & -0.01 & -0.08 & 0.15 \\
\hline Alachlor ESA & 59 & 18 & 0.01 & -0.23 & 0.20 & 0.08 & 0.01 & 0.06 \\
\hline Atrazine & 59 & 17 & 0.20 & -0.27 & 0.12 & 0.09 & 0.12 & -0.09 \\
\hline Metolachlor OXA§ & 59 & 14 & 0.53 & -0.11 & 0.28 & -0.11 & -0.14 & 0.19 \\
\hline Simazine & 59 & 14 & 0.29 & 0.08 & 0.03 & -0.12 & 0.05 & 0.39 \\
\hline Metolachlor & 59 & 12 & 0.25 & 0.03 & 0.33 & -0.20 & -0.15 & 0.01 \\
\hline \multicolumn{9}{|c|}{ Acetochlor/metolachlor } \\
\hline ESA, second amide & 59 & 5 & 0.21 & -0.04 & 0.36 & -0.12 & -0.19 & 0.14 \\
\hline Acetochlor ESA & 59 & 2 & 0.07 & -0.22 & 0.10 & -0.07 & 0.04 & -0.08 \\
\hline Acetochlor OXA & 59 & 2 & 0.08 & -0.24 & -0.13 & -0.07 & 0.19 & -0.23 \\
\hline Acetochlor & 59 & 1 & -0.13 & 0.10 & -0.04 & -0.05 & -0.08 & -0.19 \\
\hline Alachlor & 59 & 1 & 0.11 & 0.15 & 0.04 & 0.31 & 0.19 & 0.12 \\
\hline Alachlor OXA & 59 & 1 & -0.10 & -0.01 & -0.05 & -0.05 & 0.26 & -0.10 \\
\hline Alachlor SAAף & 59 & 1 & 0.04 & -0.20 & -0.08 & -0.05 & 0.13 & -0.12 \\
\hline Metribuzin & 59 & 1 & 0.19 & -0.18 & 0.16 & 0.29 & -0.08 & 0.05 \\
\hline
\end{tabular}

of this hypothesis, and it is impossible to rule out alternative explanations. Smaller pesticide concentrations in older and/or more reduced water also could be the result of (i) the mixing of recently recharged waters with older water containing no pesticides and (ii) long-term changes in farming practices (Fig. 5A) and local changes in land use or crops. Despite the uncertainties, two distinct types of agriculturally affected ground water have been identified among the four study sites. Region I contains young, oxic water with high pesticide concentration, and region II contains older, reduced water with low pesticide concentrations.

Samples plotting in region III had low $\mathrm{O}_{2}\left(\mathrm{O}_{2}<\right.$ $\left.0.10 \mathrm{mmol} \mathrm{L}^{-1}\right)$, and little or no excess $\mathrm{N}_{2}$ was present $\left(<0.12 \mathrm{mmol} \mathrm{L}^{-1}\right)$ (Fig. 6). This group of samples also had the oldest median age of water among the three regions ( $42 \mathrm{yr}$ ). Only $27 \%$ of samples in region III contained one or more pesticides. Samples plotting in region III were consistent with water recharged before the extensive use of commercial fertilizers and pesticides began. All four study sites have a long history of agriculture, so it is unlikely that any of the water was recharged before the agricultural development of the areas. Nationwide sales records of commercial fertilizer (Fig. 5B) show a fourfold increase in annual nitrogen applications since the mid-1950s. The lack of excess $\mathrm{N}_{2}$ in low- $\mathrm{O}_{2}$ water indicates that no denitrification had occurred in this older water, which is probably related to low applications of nitrogen and the use of traditional organic nitrogen sources (e.g., manure and plant material) at the time this water was recharged. Similarly, low concentrations and infrequent detections of pesticides are related to the few pesticides available on the market before the 1960s. Atrazine and simazine were registered in 1959 and 1958, respectively. The adoption and use of these two compounds increased substantially during the late 1960s and 1970s (Fig. 5A). Other pesticides frequently detected in this study came on the market lateralachlor in 1969, metolachlor in 1977, and acetochlor in 1994.

During the next $50 \mathrm{yr}$, ground water that is not currently affected by commercial fertilizer and pesticides will be replaced by water that does reflect the use and effects of significant amounts of pesticides, nitrogen, and other by-products of the modern agricultural landscape. The effectiveness with which the Nation's aquifers can naturally attenuate these chemicals, particularly complex organic pesticides, is largely unknown.

\section{Discussion}

\section{Occurrence and Fate of Triazines}

Atrazine and its degradate deethylatrazine were the primary triazine compounds detected in ground water samples from each of the four study areas, so the discussion in this section focuses on these two compounds. Atrazine can be biodegraded in soils, but as seen from samples from this study, the parent compound and deethylatrazine were detected in the shallowest wells and in some of the deepest wells. Therefore, for atrazine, degradation rates are generally slower than rates of transport. Although most degradation of atrazine probably occurs in the UZ, further degradation and perhaps mineralization can occur in the saturated zone.

Atrazine was applied to fields during the $2 \mathrm{yr}$ before collection at the MD and WA study sites and during the year of sample collection at the NE and the CA study sites. Because all of the study sites were in areas of long-term corn production, it is likely that atrazine was used at all of the study sites for many years before the collection of samples for this study.

The MD and NE study sites had the greatest overall frequency of detection and concentrations of atrazine and deethylatrazine in ground water samples. Atrazine and deethylatrazine concentrations were comparable at the NE site and in the areal wells at the MD site. Samples from the MD flow-system wells, however, had much larger deethylatrazine concentrations relative to atrazine (Fig. 3A) and, where comparable, to those in ground water samples from other study sites. Deethylatrazine at the MD site was detected in every flow-system well except the deepest well at the head of the flow system and in all but one areal well. Atrazine was detected only in the shallowest wells and in the intermediate well at the end 
Table 2. Cont'd.

\begin{tabular}{|c|c|c|c|c|c|c|c|c|c|}
\hline & Excess $\mathrm{N}_{2^{\prime}}$ gas & $\begin{array}{l}\mathrm{SO}_{4}^{-} \text {as S, } \\
\text { filtered }\end{array}$ & $\begin{array}{l}\text { Ferrous } \mathrm{Fe}, \\
\text { filtered }\end{array}$ & Mn, filtered & $\begin{array}{l}\text { Organic C, } \\
\text { filtered }\end{array}$ & $\begin{array}{l}\text { Specific UV absorbance } \\
\text { at } 254 \mathrm{~nm}\end{array}$ & $\begin{array}{c}\text { Acid volatile S plus pyritic } \mathrm{S}, \\
\text { solids }\end{array}$ & $\begin{array}{c}\begin{array}{c}\text { Ferrous Fe, } \\
\text { solids }\end{array} \\
\end{array}$ & $\begin{array}{c}\text { Organic C, } \\
\text { solid }\end{array}$ \\
\hline Metolachlor ESA† & 0.06 & -0.34 & 0.18 & 0.31 & -0.52 & 0.10 & -0.62 & -0.49 & 0.35 \\
\hline Deethylatrazine & -0.15 & -0.37 & 0.19 & 0.15 & -0.46 & -0.02 & -0.59 & -0.40 & 0.20 \\
\hline Alachlor ESA & 0.13 & -0.19 & 0.23 & 0.27 & -0.20 & -0.05 & -0.33 & -0.11 & -0.02 \\
\hline Atrazine & 0.09 & -0.07 & 0.24 & 0.36 & -0.21 & -0.08 & -0.22 & -0.13 & -0.11 \\
\hline Metolachlor OXA§ & -0.07 & -0.30 & 0.13 & 0.19 & -0.31 & 0.16 & -0.51 & -0.37 & 0.22 \\
\hline Simazine & -0.03 & 0.23 & -0.13 & 0.08 & 0.13 & 0.36 & 0.15 & -0.09 & 0.11 \\
\hline Metolachlor & -0.12 & -0.47 & 0.16 & 0.11 & -0.50 & -0.16 & -0.47 & -0.20 & -0.01 \\
\hline \multicolumn{10}{|c|}{ Acetochlor/metolachlor } \\
\hline ESA, second amide & -0.08 & -0.43 & 0.06 & 0.00 & -0.38 & -0.01 & -0.35 & 0.03 & 0.34 \\
\hline Acetochlor ESA & -0.12 & -0.17 & 0.08 & 0.20 & 0.09 & 0.14 & 0.22 & 0.23 & -0.17 \\
\hline Acetochlor OXA & 0.10 & -0.01 & 0.14 & 0.16 & 0.16 & 0.27 & 0.22 & 0.23 & -0.17 \\
\hline Acetochlor & 0.18 & 0.07 & 0.21 & 0.20 & -0.08 & 0.22 & NA & NA & -0.12 \\
\hline Alachlor & -0.02 & -0.11 & -0.13 & -0.05 & 0.05 & 0.11 & -0.06 & 0.00 & 0.10 \\
\hline Alachlor OXA & 0.19 & 0.05 & -0.13 & 0.10 & -0.22 & -0.21 & NA & NA & -0.12 \\
\hline Alachlor SAAף & 0.01 & -0.04 & 0.00 & 0.11 & 0.19 & 0.17 & 0.22 & 0.23 & -0.12 \\
\hline Metribuzin & 0.00 & -0.02 & 0.19 & 0.08 & -0.13 & 0.02 & -0.25 & -0.05 & 0.24 \\
\hline
\end{tabular}

† ESA, ethanesulfonic acid.

\# Values in italics are statistically significant correlations $(\alpha=0.05)$.

$\S$ OXA, oxanilic acid.

I $S A A$, sufinylacetic acid.

of the flow system, and where atrazine was detected it was present at concentrations one to two orders of magnitude less than deethylatrazine (except for one areal well). At the NE study site, atrazine and deethylatrazine were detected predominantly in the water samples collected from wells within or adjacent to the corn field. Wells that contained measurable amounts of atrazine and/or deethylatrazine at the NE site were located where the water table is the deepest below land surface. In addition, Hancock et al. (2008) report that atrazine and deethylatrazine were found in the deepest lysimeters at this site, and after precipitation or irrigation, pesticides quickly moved through the $7 \mathrm{~m}$ of loess via matrix flow. Just beneath the loess is a fine-grained, well sorted sand that can transport water readily. Therefore, at the NE site, the movement of atrazine was fast enough that, although some degradation occurred, not all atrazine was degraded before it reached the ground water system.

At the CA study site, the UZ soil texture is primarily sand with a thin layer of silty sand or silt about $3 \mathrm{~m}$ deep. This deposit might inhibit some of the flow of water, but the flux of water through the UZ could be from matrix flow. Because the UZ transport is slow at this site, there is ample time within the soil horizon for atrazine to degrade to deethylatrazine, which was the predominant pesticide or pesticide degradate detected in the ground water. In fact, atrazine was not detected in samples from wells screened in the middle section of the flow system, whereas deethylatrazine was detected frequently. At the CA study site, the center cluster of flow-system wells contained oxic water, likely because of some small influx of water from the lined irrigation canal or infiltration from irrigation application of surface water.

The degradate fraction for deethylatrazine (ratio of deethylatrazine to sum of atrazine and deethylatrazine; Eq. [1]) was greater than 0.9 (mostly degradate) for samples from the MD and CA study sites, whereas samples from the NE site had fractions closer to 0.5 , which indicates relatively more parent atrazine in these samples (Fig. 3B). The fraction of deethylatrazine in ground water samples from the NE site tended to increase from the corn field toward Maple Creek. This result indicates that atrazine and deethylatrazine can persist in ground water at the NE site. Furthermore, at the NE site the fraction of deethylatrazine in water samples from the flow-system wells tended to decrease with age of ground water (Fig. 3B) and with depth of screened interval (Fig. 3C). There was little relation of the fraction of deethylatrazine to depth of screened interval in ground water from other study sites. There was no relation of the fraction of deethylatrazine to apparent age in samples from wells from the MD and CA flow systems.

Some of the samples from areal wells at the MD site contained relatively more atrazine than samples from the flow-system wells of the same age and depth to screened interval (Fig. 3B and 3C). This finding suggests that the choice of pesticide applied to particular fields (e.g., use of atrazine or not) helps determine the amount of atrazine that migrates to ground water. The fact that most young samples of water from flow-system wells at the MD, CA, and WA study sites contained relatively more deethylatrazine (>80\%) than atrazine indicates that processes occurring in the soil or UZ result in transformation of atrazine to form deethylatrazine. Relatively more deethylatrazine is formed or transported to ground water at the MD and CA sites than at the NE site. At the NE site, atrazine and deethylatrazine seem to be stable and persist for many years.

Simazine was the only other triazine herbicide that was detected in ground water samples from the study sites. Simazine, which was used at the MD, CA, and WA study sites, was detected in water samples from the areal wells at the MD and WA sites and in most flow-system wells at the CA site. At the MD and WA sites, simazine use was limited, and the compound did not reach the ground water except at localized areas. At the WA, 


\section{EXPLANATION}

Site location

Maryland

O Nebraska

○ California

$\mathrm{O}$ Washington

\begin{tabular}{l|c|c|c} 
& \multicolumn{3}{c}{ Region } \\
\hline $\begin{array}{l}\text { Median age of } \\
\text { water (years) }\end{array}$ & 8 & 23 & 42 \\
\hline $\begin{array}{l}\text { Median pesticide } \\
\text { concentration(nmol L) }\end{array}$ & 14.9 & 0.53 & 0 \\
\hline $\begin{array}{l}\text { Samples containing 1 } \\
\text { or more pesticides } \\
\text { (percent) }\end{array}$ & 89 & 86 & 27 \\
$\begin{array}{l}\text { Median detections } \\
\text { per sample }\end{array}$ & 4.5 & 3 & 0
\end{tabular}
(nmol L-1)

Not detected
(A) Total Pesticide Concentration

Pesticide concentration

of Minimum $.02 \mathrm{nmol} \mathrm{L}^{-1}$

Maximum $65.35 \mathrm{nmol} \mathrm{L}^{-1} \quad 0.25$

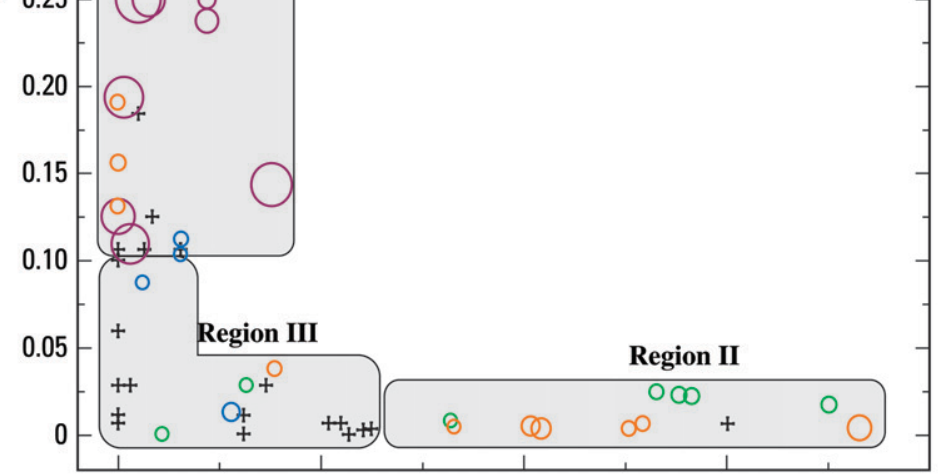

(B) Metolachlor ESA

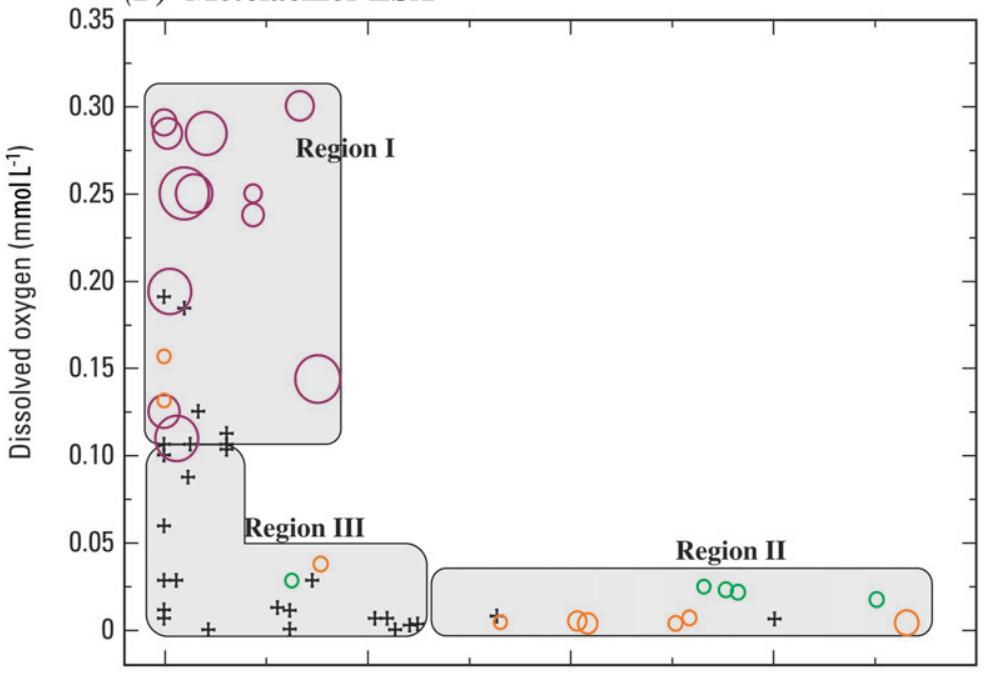

(C) Metolachlor OXA

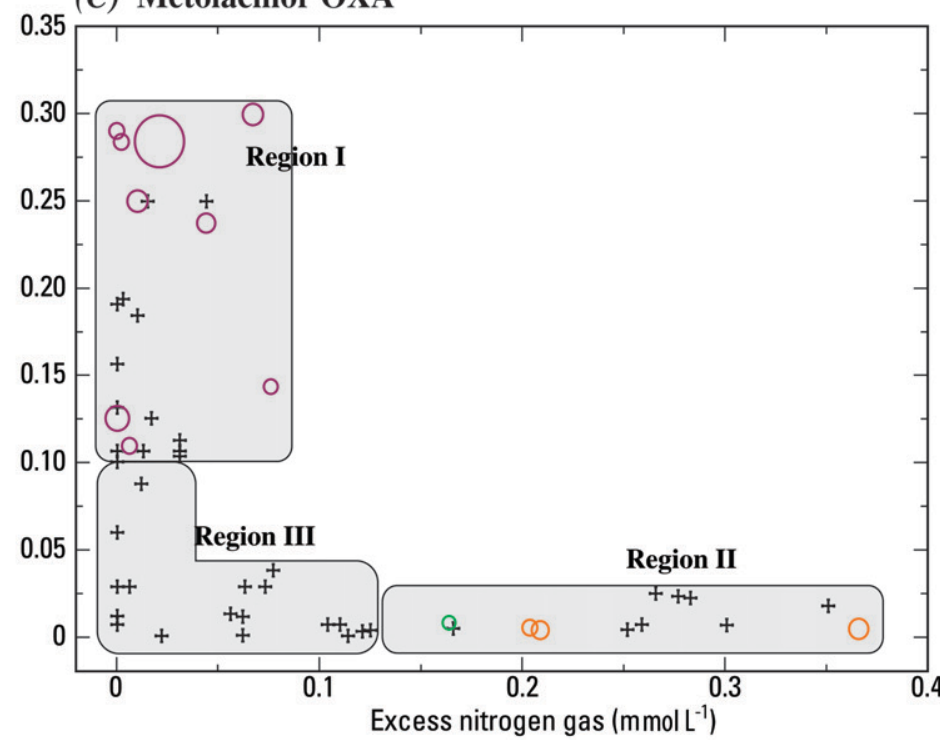

Fig. 6. Site groupings relative to dissolved oxygen and excess nitrogen gas for (A) total pesticide concentration, (B) metolachlor ethanesulfonic acid (ESA), and (C) metolachlor oxanilic acid (OXA). 
site wells where simazine was detected were adjacent to vineyards where most of the simazine is used. At the CA site, simazine was detected in 9 of 11 flow-system wells (82\%). The concentration of simazine was greatest in the shallow, upgradient wells of the flow system. Concentrations of simazine tended to decrease with depth and with proximity to the end of the flow system.

\section{Occurrence and Fate of Chloroacetanilides}

Metolachlor was the primary chloroacetanilide detected during the study (12 of 59 samples). Variations in the degradate fraction for metolachlor ESA were related to age and depth (Fig. 4B and $4 \mathrm{C}$ ) of the ground water (i.e., typically more metolachlor parent compound was detected in young and shallow water). Concentrations of metolachlor ESA in samples from the MD site were highest in samples from wells at the head of the flow system and in older, deeper water. Four samples at the MD site were clustered around 0.6 for the metolachlor ESA fraction (Fig. 4B), which indicates slightly more than one half of the sample was degradate. Other samples from the MD site generally ranged from about 0.74 to 0.99 , indicating that most of the product detected in ground water samples was metolachlor degradate and not parent compound. At all sites, none of the samples contained more parent product than degradate. The reason for this could include the varied use of metolachlor on the field through annual corn-soybean rotation and subsequent use of metolachlor on corn fields. Metolachlor has a short half-life of about $90 \mathrm{~d}$ in aerobic soils (Ahuja et al., 2000). Metolachlor had not been used on the MD field for $2 \mathrm{yr}$ before the collection of samples for this study.

At the NE site, metolachlor ESA fractions typically were between 0.99 and 1.0, indicating that almost no parent product was detected. Samples from wells near Maple Creek, however, had metolachlor ESA fractions of 0.00 , indicating that all of the metolachlor detected was the parent compound. Although the age date of the sample from the deepest well indicates water $>30 \mathrm{yr}$ old, the presence of metolachlor (registered 1977) in the sample indicates a fraction of younger water. It is likely that this water is of recent origin and was the result of flood-induced gradient reversals from high water in Maple Creek during a major storm days before the sample collection. The presence of only the metolachlor parent and neither metolachlor ESA nor metolachlor OXA lends support to a recent origin for this water; however, at the NE site the ground water flow direction is not necessarily along the flowpath, so a direct correlation between the beginning and ending wells of the transect cannot be made (e.g., the hydrologic connection between the agricultural land at the upgradient wells and the riparian wells is not necessarily 1:1).

Samples from the CA flow system also showed a trend of increasing metolachlor ESA (an less metolachlor) with age. Metolachlor ESA fractions ranged from 0.70 to 1.0 , indicating that relatively little parent compound was present in the sample. The three samples containing the smaller metolachlor ESA fraction $(0.7-0.8)$ were from wells at the head of the flow system and from the three deepest wells of that well cluster. The smaller metolachlor ESA fractions are at the head of the flow system and in a recharge area reveals that metolachlor has not been in the system as long as at most of the other well clusters (verified by the age dates).
The proportion of metolachlor in ground water generally was far less than that of its degradates (Fig. 7). As metolachlor moves through the UZ, most of it degrades to metolachlor ESA and/or metolachlor OXA. At the MD site, the UZ rarely had concentrations of metolachlor concomitant with metolachlor ESA and metolachlor OXA, but at the NE, site metolachlor was concomitant with its degradates. The relative percentages of metolachlor present as parent compound, metolachlor ESA, and metolachlor OXA are evident in Fig. 7, which shows most samples clustered toward the tip of the ternary diagram, indicating that metolachlor ESA is the predominant constituent. Figure 7 also shows that many of the samples from the MD site plot in the area of larger concentrations of metolachlor ESA and metolachlor OXA on the ternary diagram, indicating that although metolachlor ESA is the predominant degradate, metolachlor OXA is still present, unlike in most of the samples from the NE and CA sites. Because metolachlor ESA is more persistent than metolachlor OXA, the ratio of metolachlor OXA to metolachlor ESA changes over time, so that once the chemicals are in the ground water, metolachlor ESA eventually becomes the dominant species. This also seems to be occurring in the UZ just above the sampling depth of the shallow wells (Hancock et al., 2008).

Alachlor ESA, the third most frequently detected pesticide or pesticide degradate, was found in 18 of 59 ground water samples (31\%). Although the use of alachlor largely has been discontinued over the past decade, its degradate alachlor ESA was detected frequently at three of the four study sites. Most of these detections were in samples from areas where corn is the predominant crop. Nevertheless, no detections of the parent compound alachlor, which once was commonly used on corn fields, were seen. Therefore, the use of alachlor has waned over the years, and it likely was replaced, at least in part, with acetochlor (Fig. 5A). Consequently, over time, alachlor, which has a half-life of about $15 \mathrm{~d}$ in soils (Ahuja et al., 2000), has metabolized to its daughter products-alachlor ESA, alachlor OXA, and alachlor SAA [2-(\{[N-(2,6 diphenyl)-N-(methoxymethyl)carbamoyl $]$ methyl $\}$ sulfinyl)acetic acid]. Alachlor OXA and alachlor SAA were detected in only one water sample each and always in concert with alachlor ESA. This finding suggests that alachlor ESA is the predominant degradate and persists in ground water for years. Although no current health advisory exists for alachlor ESA, there exists a drinking water standard of $7.4 \mathrm{nmol} \mathrm{L}^{-1}$ for alachlor, which may cause potential human health effects (USEPA, 2006).

\section{Results of Root-Zone Water-Quality Model Simulations}

To better understand pesticide movement to the water table, the Root-Zone Water-Quality Model (RZWQM) (Ahuja et al., 2000) was used to simulate the movement of metolachlor and two of its common degradation products-metolachlor ESA and metolachlor OXA - through the UZ at the MD site. The RZWQM developed for this study was modified to simulate chemical movement to $10 \mathrm{~m}$ below land surface (Bayless et al., 2008). Depths to water in the simulation ranged from 4.82 to $5 \mathrm{~m}$. For purposes of the model, based on soil cores the soil horizon and the UZ consisted of the following: 0 to $2 \mathrm{~m}$, sandy loam; 2 to 5 $\mathrm{m}$, loam; and 5 to $6 \mathrm{~m}$, sandy loam (Fig. 8). The chemical proper- 


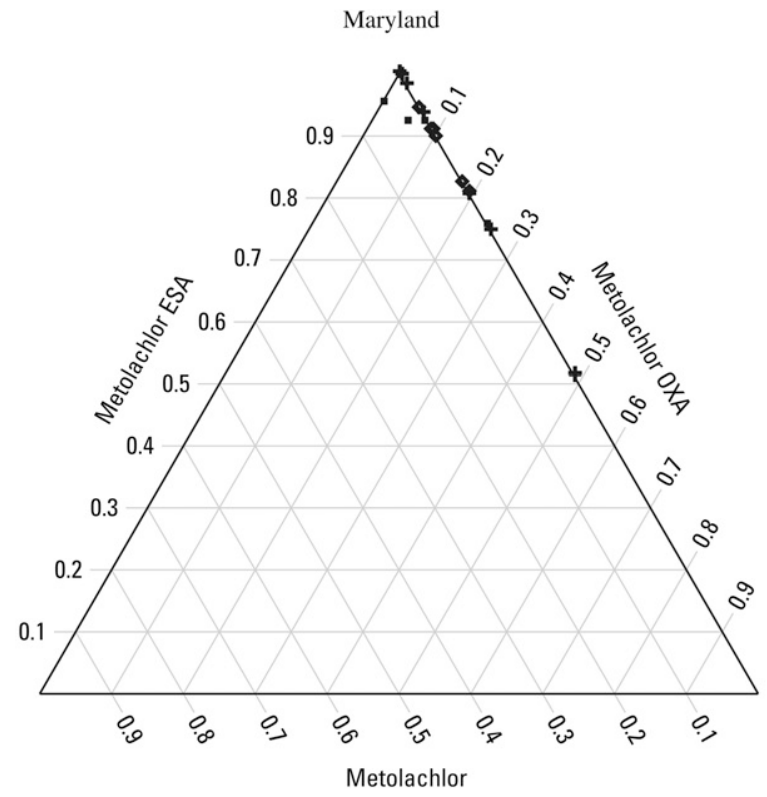

EXPLANATION

Ground-water

site type

- Areal well

+ Flow-system well

$\diamond$ Unsaturated zone

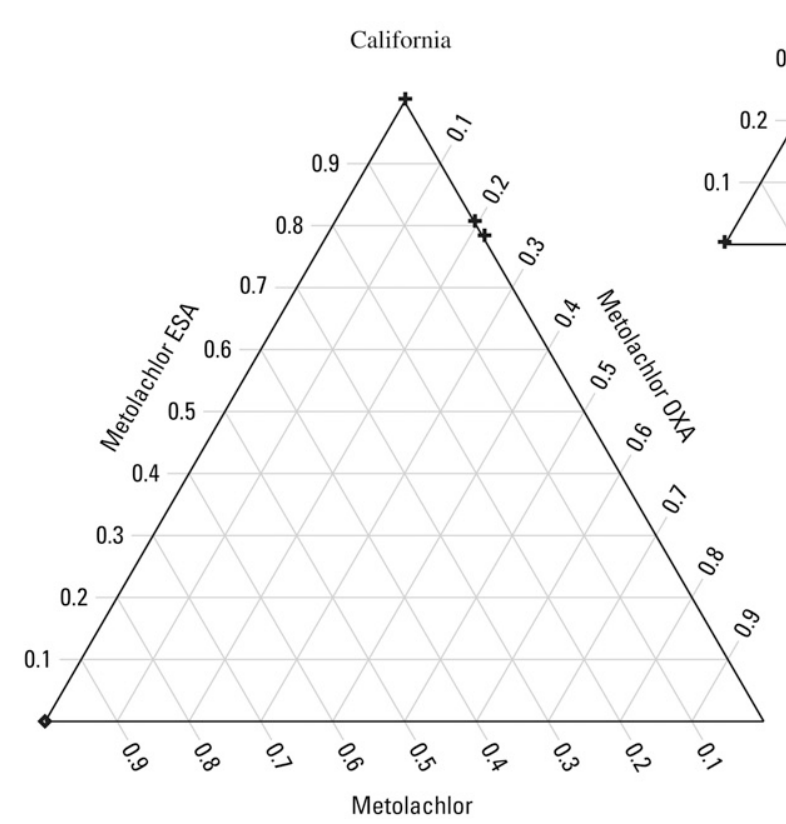

Fig. 7. Ternary plot of metolachlor and metolachlor ethanesulfonic acid (ESA) and oxanilic acid (OXA) degradates in the deepest unsaturated zone and in ground water samples from (A) Maryland, (B) Nebraska, and (C) California study sites.

ties used for the simulation were $\mathrm{K}$ and soil dissipation half-life $\left(\mathrm{t}_{1 / 2, \text { soil }}\right.$ in days: metolachlor $\mathrm{K}_{\mathrm{oc}}=182, \mathrm{t}_{1 / 2, \text { soil }}=10 \mathrm{~d}$; metolachlor $\mathrm{ESA} \mathrm{K}_{\mathrm{oc}}=13.5, \mathrm{t}_{1 / 2, \text { soil }}=70 \mathrm{~d}$; and metolachlor OXA K $\mathrm{oc}_{\mathrm{oc}}=17$, $\mathrm{t}_{1 / 2 \text {, soil }}=50 \mathrm{~d}$ ) (Bayless et al., 2008). It was assumed that corn and soybeans were grown in alternating years beginning with corn in year 1 (simulation year 1976). Metolachlor was applied only in the years that corn was planted (alternating years beginning with year 3 of the simulation). The 30-yr simulation assumed that of metolachlor and its degradates concentrations were equal to zero at the beginning of the modeled period. The first simulated year of metolachlor application was 1978, $1 \mathrm{yr}$ after the compound was registered for use. The metolachlor application rate was held constant at $2.2 \mathrm{~kg} \mathrm{ha}^{-1}$ from 1977 through 2001 and then reduced to $1.4 \mathrm{~kg} \mathrm{ha}^{-1}$ to simulate conversion to the use of S-metolachlor. Root-zone water-quality model was calibrated using a best-fit simulation and sensitivity analysis of two soil transport parameters$\mathrm{K}_{\mathrm{oc}}$ and $\mathrm{t}_{1 / 2 \text {, soil }}$.

The simulation predicted that the degradates of metolachlor would be transported through the soil zone much faster and to a greater depth than would the parent product. Results of RZWQM simulations (Fig. 8) generally agree with metolachlor, metolachlor ESA, and metolachlor OXA values in water samples from the UZ 

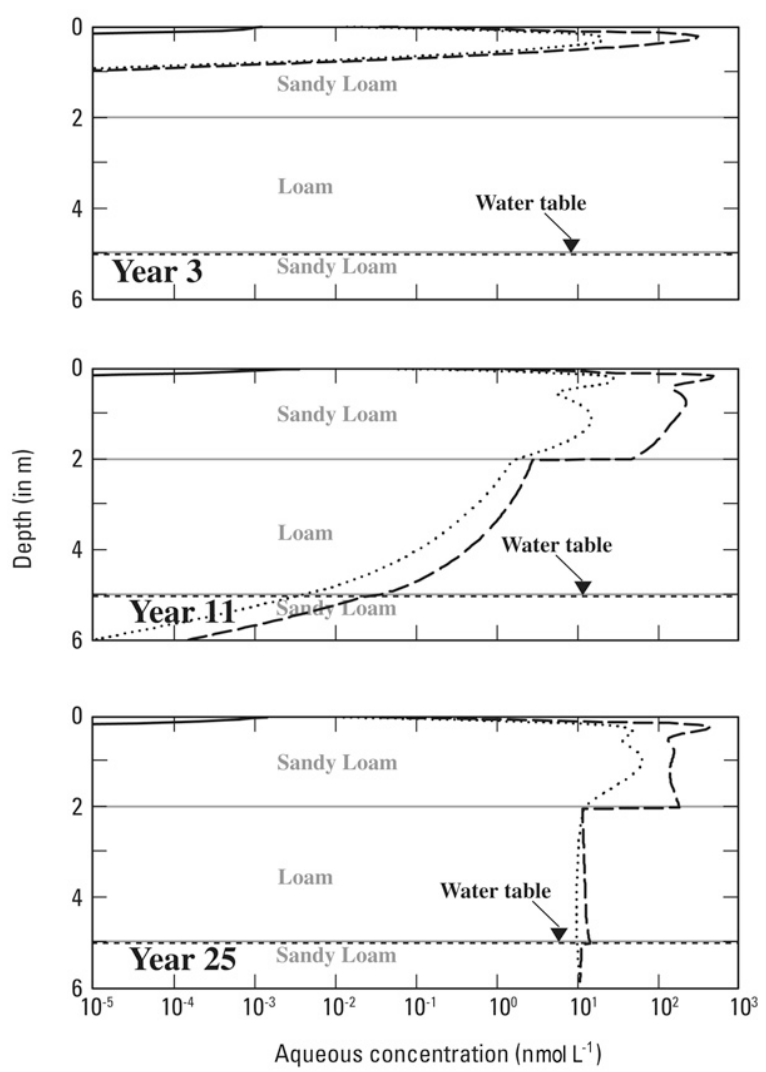

EXPLANATION

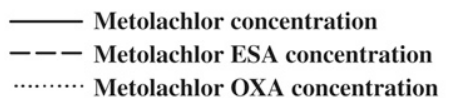

Fig. 8. Root-zone water-quality model predictions of pesticide movement to ground water at Maryland study site.

as to which product should be at a greater concentration (e.g., the predominant species). The RZWQM simulation predicts that after the first year of metolachlor application, the total mass of metolachlor will have moved to a maximum depth of $0.15 \mathrm{~m}$ into the soil and that the concentrations of the total mass of metolachlor at that time will remain constant throughout the simulation. Metolachlor ESA and metolachlor OXA, however, will move about $1 \mathrm{~m}$ into the $\mathrm{UZ}$ after the first year, and, after $11 \mathrm{yr}$, these compounds will have moved well into the soil profile, ultimately reaching and exceeding the depth of the water table $(5 \mathrm{~m})$. In addition, concentrations of metolachlor ESA and metolachlor OXA will have increased to more than $100 \mathrm{nmol} \mathrm{L}^{-1}$ in the top $2 \mathrm{~m}$ of sandy loam. This "accumulation" of degradates in the upper $2 \mathrm{~m}$ is associated with the soil type because the sandier loam retains much of the pesticides. Within the UZ, concentrations of metolachlor ESA always are greater than those of metolachlor OXA, especially in the shallowest soil zone (0-2 m). After $25 \mathrm{yr}$ of simulation, the metolachlor concentration profile remains virtually identical to the profile for year 3. The simulated distribution of metolachlor and its degradates corresponds with field observations in this study. Metolachlor was rarely detected in ground water, and the simulation shows nearly complete loss of the parent product in the upper
$0.5 \mathrm{~m}$ of the soil profile. The simulated distribution of metolachlor ESA and metolachlor OXA in the UZ generally corresponds to field observations from this study. At the MD site, metolachlor ESA and metolachlor OXA were always detected in the same sample, and metolachlor ESA typically was detected at larger concentrations than metolachlor OXA. Although the MD site was the simplest and best characterized of the four study sites, RZWQM simulation for this study generally simulated field observations of metolachlor and its two most common degradates. Although actual simulated concentrations versus field concentrations of the constituents varied, RZWQM simulated metolachlor ESA as the dominant degradate in the UZ.

\section{Summary}

The occurrence and fate of pesticides in ground water flow systems in four agricultural areas of the USA were investigated. Analyses of samples collected from a network of 59 wells indicate the presence of pesticides in ground water in all four areas-MD, NE, CA, and WA; the most frequently detected compounds were the degradates of the triazine and chloroacetanilide classes of herbicides. No insecticides were detected in the water samples from any of the study sites. On the other hand, atrazine and its degradate deethylatrazine were detected in samples from each study site. Furthermore, alachlor ESA, metolachlor, metolachlor ESA, and metolachlor OXA were detected in water samples from three of the four study sites.

A modified version of RZWQM was used to understand movement and fate of metolachlor through the $\mathrm{UZ}$ at the MD study site. Results of a 30-yr simulation generally agreed with data for samples from the UZ. The root-zone water-quality model predicted that the concentrations of metolachlor ESA would be larger then metolachlor OXA in the UZ. Analyses of samples from the MD site indicated that in most cases, concentrations of metolachlor ESA were greater than those of metolachlor OXA. Therefore, the model seems to generally represent degradation of metolachlor in the UZ.

The proportion of metolachlor in ground water was far less than its degradates, and metolachlor ESA was the predominant degradate. Although metolachlor OXA was present in some water samples, it seemed that the ratio of metolachlor OXA to metolachlor ESA changed with time and that metolachlor ESA was more persistent in ground water; thus, when both were present, metolachlor ESA eventually became the dominant species.

Atrazine and deethylatrazine persisted in ground water at the NE site, whereas atrazine seemed to dealkylate to deethylatrazine at the MD and CA sites. Furthermore, the fraction of deethylatrazine tended to decrease with age of ground water at the NE site, which probably is a function of its total mineralization or its limited use in the late 1950s or early 1960s. In water samples from the other three study sites, there was little change in fraction of deethylatrazine, and most of the youngest samples had relatively more deethylatrazine, which suggests processes occurring in the $\mathrm{UZ}$ before the transformation of atrazine to deethylatrazine. Relatively more deethylatrazine was formed or transported to ground water at the MD and CA sites than 
at the NE site. At the NE site, atrazine and deethylatrazine seemed to be stable and persist for many years.

\section{Acknowledgments}

This study was conducted as part of the U.S. Geological Survey's National Water-Quality Assessment (NAWQA) Program, Agricultural Chemicals: Sources, Transport, and Fate study. The authors thank Elizabeth Frick, Steven Kalkhoff, and Chet Zenone (emeritus) of the U.S. Geological Survey and three anonymous reviewers for valuable comments on the manuscript.

\section{References}

Accinelli, C., G. Dinelli, A. Vicari, and P. Catizone. 2001. Atrazine and metolachlor degradation in subsoils. Biol. Fertil. Soils 33:495-500.

Agertved, J., K. Rugge, and J.F. Barker. 1992. Transformation of the herbicides MCPP and atrazine under natural aquifer conditions. Ground Water 30:500-506.

Ahuja, L.R., K.W. Rojas, J.D. Hanson, M.J. Shaffer, and L. Ma (ed.). 2000. Root zone water-quality model-Modeling management effects on water quality and crop production. Water Resour. Pub., LLC, Highlands Ranch, CO.

Barbash, J.E., and E.A. Resek. 1996. Pesticides in ground water: Distribution, trends, and governing factors. Ann Arbor Press, Chelsea, MI.

Barbash, J.E., G.P. Thelin, D.W. Kolpin, and R.J. Gilliom. 1999. Distribution of major herbicides in ground water of the United States. Water-Resour. Inv. Rep. 98-4245. USGS, Sacramento, CA.

Bayless, E.R. 2001. Atrazine retention and degradation in the vadose zone at a till plain site in central Indiana. Ground Water 39:169-180.

Bayless, E.R., P.D. Capel, J.E. Barbash, R.M.T. Webb, T.C. Hancock, and D.C. Lampe. 2008. Simulated fate and transport of metolachlor in the unsaturated zone, Maryland, USA. J. Environ. Qual. 37:1064-1072.

Betlach, M.R., and J.M. Tiedje. 1981. Kinetic explanation for accumulation of nitrite, nitric oxide, and nitrous oxide during bacterial denitrification. Appl. Environ. Microbiol. 42:1074-1084.

Bosch, D.D., and C.C. Truman. 2002. Agrichemical transport to groundwater through coastal plain soils. Trans. ASAE 45:1385-1396. Available at http://sacs.cpes.peachnet.edu/sewrl/bosch/ 2002\%20Bosch\%20TASAE\%2045(5)\%20Agrichemical\%20 transport $\% 20$ to $\% 20$ groundwater\%20through\%20CP\%20soils.pdf (verified 12 Oct. 2007).

Burow, K.R., S.Y. Panshin, N.M. Dubrovsky, D. van Brocklin, and G.E. Fogg. 1999. Evaluation of processes affecting 1,2-dibromo-3chloropropane (DBCP) concentrations in ground water in the eastern San Joaquin Valley, California: Analysis of chemical data and groundwater flow and transport simulations. Water-Resour. Inv. Rep. 99-4059. USGS, Sacramento, CA.

Capel, P.D., K.A. McCarthy, and J.E. Barbash. 2008. National, holistic watershed-scale approach for studying agricultural chemicals. J. Environ. Qual. 37:983-993.

Childress, C.J., W.T. Foreman, B.F. Connor, and T.J. Maloney. 1999. New reporting procedures based on long-term method detection levels and some considerations for interpretations of water-quality data provided the U.S. Geological Survey National Water Quality Lab. Open-File Rep. 99-133. USGS, Richmond, VA.

Crespín, M.A., M. Gallego, M. Valcárcel, and J.L. González. 2001. Study of the degradation of the herbicides 2,4-D and MCPA at different depths in contaminated agricultural soil. Environ. Sci. Technol. 35:4265-4270.

Delin, G.N., and M.K. Landon. 2002. Effects of surface run-off on the transport of agricultural chemicals to ground water in a sandplain setting. Sci. Total Environ. 295:143-155.

Fenelon, J.M., and R.C. Moore. 1998. Transport of agrichemicals to ground and surface water in a small central Indiana watershed. J. Environ. Qual. 27:884-894.

Freeze, R.A., and J.A. Cherry. 1979. Groundwater. Prentice Hall, Englewood Cliffs, NJ.

Fredrick, B.S., J.I. Linard, and J.L. Carpenter. 2006. Environmental setting of the Maple Creek watershed, Nebraska. Scientific Inv. Rep. 2006-5037. USGS, Lincoln, NE.
Gilliom, R.J., J.E. Barbash, C.G. Crawford, P.A. Hamilton, J.D. Martin, N. Nakagaki, L.H. Nowell, J.C. Scott, P.E. Stackelberg, G.P. Thelin, and D.M. Wolock. 2006. The quality of our nation's waters-Pesticides in the Nation's streams and ground water, 1992-2001. Circ. 1291. USGS, Washington, DC. Available at http://ca.water.usgs.gov/pnsp/pubs/ circ1291/ (verified 12 Oct. 2007).

Green, C.T., L.J. Puckett, J.K. Böhlke, B.A. Bekins, S.P. Phillips, L.J. Kauffman, J.M. Denver, and H.M. Johnson. 2008. Limited occurrence of denitrification in four shallow aquifers in agricultural areas of the United States. J. Environ. Qual. 37:994-1009.

Gronberg, J.M., and C.R. Kratzer. 2006. Environmental setting of the lower Merced River Basin, California. Scientific Inv. Rep. 2006-5152. USGS, Sacramento, CA.

Groschen, G.E., T.L. Arnold, M.A. Harris, D.H. Dupré, F.A. Fitzpatrick, B.C. Scudder, W.S. Morrow, Jr., P.J. Terrio, K.L. Warner, and E.A. Murphy. 2004. Water quality in the upper Illinois River Basin, Illinois, Indiana, and Wisconsin, 1999-2001. Circ. 1230. USGS, Washington, DC. Available at http://water.usgs.gov/pubs/circ/2004/1230/ (verified 12 Oct. 2007).

Hancock, T.C., M.W. Sandstrom, J.R. Vogel, R.M.T. Webb, E.R. Bayless, and J.E. Barbash. 2008. Transport and fate of pesticides in the unsaturated zone within five agricultural settings of the United States. J. Environ. Qual. 37:1086-1100.

Hancock, T.C., and M.J. Brayton. 2006. Environmental setting of the Morgan Creek Basin, Maryland, 2002-04 Open-File Rep. 2006-1151. USGS, Richmond, VA.

Hladik, M.L., J.J. Hsiao, and A.L. Roberts. 2005. Are neutral chloroacetamide herbicide degradates of potential environmental concern? Analysis and occurrence in the upper Chesapeake Bay. Environ. Sci. Technol. 39:6561-6574.

Kalkhoff, S.J., D.W. Kolpin, E.M. Thurman, I. Ferrer, and D. Barcelo. 1998. Degradation of chloroacetanilide herbicides: The prevalence of sulfonic and oxanilic acid metabolites in Iowa groundwaters and surface waters. Environ. Sci. Technol. 32:1738-1740.

Kiely, T., D. Donaldson, and A. Grube. 2004. Pesticides industry sales and usage-2000 and 2001 market estimates. USEPA Rep. 733-R-04-001. U.S. Gov. Print. Office, Washington, DC. Available at www.epa.gov/oppbead1/ pestsales/01 pestsales/table_of_contents2001.html (verified 12 Oct. 2007).

Kolpin, D.W. 1997. Agricultural chemicals in groundwater of the Midwestern United States: Relations to land use. J. Environ. Qual. 26:1025-1037.

Kolpin, D.W., J.E. Barbash, and R.J. Gilliom. 2002. Atrazine and metolachlor occurrence in shallow ground water of the United States, 1993 to 1995: Relations to explanatory factors. J. Am. Water Resour. Assoc. 38:301-311.

Kolpin, D.W., S.J. Kalkhoff, D.A. Goolsby, D.A. Sneck-Fahrer, and E.M. Thurman. 1997. Occurrence of selected herbicides and herbicide degradation products in Iowa's ground water, 1995. Ground Water 35:679-688.

Kolpin, D.W., E.M. Thurman, and D.A. Goolsby. 1996. Occurrence of selected pesticides and their metabolites in near-surface aquifers of the midwestern United States. Environ. Sci. Technol. 30:335-340.

Kolpin, D.W., E.M. Thurman, and S.M. Linhart. 2000. Finding minimal herbicide concentrations in ground water? Try looking for their degradates. Sci. Total Environ. 248:115-122.

Kruger, E.L., L. Somasundaram, R.S. Kanway, and J.R. Coats 1993. Persistence and degradation of $\left[{ }^{14} \mathrm{C}\right]$ atrazine and $\left[{ }^{14} \mathrm{C}\right]$ deisopropylatrazine as affected by soil depth and moisture conditions. Environ. Toxicol. Chem. 12:1959-1967.

Larsen, L., S.R. Sørensen, and J. Aamand. 2000. Mecoprop, isoproturon, and atrazine in and above a sandy aquifer: Vertical distribution of mineralization potential. Environ. Sci. Technol. 34:2426-2430.

Lee, E.A., and A.P. Strahan. 2003. Methods of analysis by the U.S. Geological Survey Organic Geochemistry Research Group-Determination of acetamide herbicides and their degradation products in water using online solid-phase extraction and liquid chromatography/mass spectrometry. Open-File Rep. 03-173. USGS, Lawrence, KS.

McCarty, P.L., M. Reinhard, and B.E. Rittmann. 1981. Trace organics in groundwater. Environ. Sci. Technol. 15:40-51.

McMahon, P.B., K.F. Dennehy, B.W. Bruce, J.K. Böhlke, R.L. Michel, J.J. Grudak, and D.B. Hurlbut. 2006. Storage and transit time of chemicals in thick unsaturated zones under rangeland and irrigated cropland, High Plains, United States. Water Resour. Res. 42:W03413 doi:10.1029/2005WR004417.

Mills, P.C., D.W. Kolpin, E.A. Scribner, and E.M. Thurman. 2005. Herbicides and degradates in shallow aquifers of Illinois: Spatial and 
temporal trends. J. Am. Water Resour. Assoc. 41:537-547.

National Agriculture Statistics Service. 2006. National statistics for pesticide management. USDA, Washington, DC. Available at http://www. pestmanagement.info/nass/ (verified 12 Oct. 2007).

Ou, L.-T., J.E. Thomas, K.S.V. Edvardsson, P.S.C. Rao, and W.B. Wheeler. 1986. Aerobic and anaerobic degradation of aldicarb in aseptically collected soils. J. Environ. Qual. 15:356-363.

Panno, S.V., and W.R. Kelly. 2004. Nitrate and herbicide loading in two groundwater basins of Illinois' sinkhole plain. J. Hydrol. 290:229-242.

Payne, K.L., H.M. Johnson, and R.W. Black. 2007. Environmental setting of the Granger Drain and DR2 Basins, Washington, 2003-2004. Scientific Inv. Rep. 2007-5102. USGS, Portland, OR.

Phillips, P.J., G.R. Wall, E.M. Thurman, D.Q. Eckhardt, and J. vanHoesen. 1999. Metolachlor and its metabolites in tile drain and stream runoff in the Canajoharie Creek watershed. Environ. Sci. Technol. 33:3531-3537.

Postle, J.K., B.D. Rheineck, P.E. Allen, J.O. Baldock, C.J. Cook, R. Zogbaum, and J.P. Vandenbrook. 2004. Chloroacetanilide herbicide metabolites in Wisconsin groundwater: 2101 survey results. Environ. Sci. Technol. 38:5339-5343.

Puckett, L.J., and W.B. Hughes. 2005. Transport and fate of nitrate and pesticides - hydrogeology and riparian zone processes. J. Environ. Qual. 34:2278-2292.

Schwarzenbach, R.P., P.M. Gschwend, and D.M. Imboden. 1993. Environmental organic chemistry. John Wiley \& Sons, NY.

Scribner, E.A., E.M. Thurman, D.A. Goolsby, M.T. Meyer, W.A. Battaglin, and D.W. Kolpin. 2005. Summary of significant results from studies of triazine herbicides and their degradation products in surface water, ground water, and precipitation in the midwestern United States during the 1990s. Scientific Inv. Rep. 2005-5094. USGS, Lawrence, KS.

Smith, R.L., J.K. Böhlke, S.P. Garabedian, K.M. Revesz, and T. Yoshinari.
2004. Assessing denitrification in groundwater using natural gradient tracer tests with ${ }^{15} \mathrm{~N}$ : In situ measurement of a sequential multistep reaction. Water Resour. Res. 40:W07101 doi:10.1029/2003WR002919.

Stamper, D.M., and O.H. Tuovinen. 1998. Biodegradation of the acetanilide herbicides alachlor, metolachlor, and propachlor. Crit. Rev. Microbiol. 24:1-22.

Tesoriero, A.J., H. Liebscher, and S.E. Cox. 2000. Mechanism and rate of denitrification in an agricultural watershed: Electron and mass balance along groundwater flow paths. Water Resour. Res. 36:1545-1559.

Tesoriero, A.J., D.A. Saad, K.R. Burow, E.A. Frick, L.J. Puckett, and J.E. Barbash. 2007. Linking ground-water age and chemistry data along flow paths: Implications for trends and transformations of nitrate and pesticides: J. Contam. Hydrol. 94:139-155.

Tesoriero, A.J., F.E. Löffler, and H. Liebscher. 2001. Fate and origin of 1,2-dichloropropane in an unconfined shallow aquifer. Environ. Sci. Technol. 35:455-461.

USGS. 2007. National field manual for the collection of water-quality data. Tech. Water-Res. Inv. book 9, Chaps. A1-A9. USGS, Reston, VA. Available at http://pubs.water.usgs.gov/twri9A (verified 12 Oct. 2007).

USEPA. 2006. Drinking water contaminants. USEPA, Washington, DC. Available at http://www.epa.gov/safewater/contaminants/index.html (verified 12 Oct. 2007).

Veeh, R.H., W.P. Inskeep, and A.K. Camper. 1996. Soil depth and temperature effects on microbial degradation of 2,4-D. J. Environ. Qual. 25:5-12.

Vinther, F.P., L. Elsgaard, and O.S. Jacobson. 2001. Heterogeneity of bacterial populations and pesticide degradation potentials in the unsaturated zone of loamy and sandy soils. Biol. Fertil. Soils 33:514-520.

Winkelmann, D.A., and S.J. Klaine. 1991. Degradation and bound residue formation of atrazine in a western Tennessee soil. Environ. Toxicol. Chem. 10:335-345. 